Article

\title{
Comparative Chemical Profiling and Monacolins Quantification in Red Yeast Rice Dietary Supplements by ${ }^{1}$ H-NMR and UHPLC-DAD-MS
}

\author{
Rabab Hachem ${ }^{1}$, Gaëtan Assemat ${ }^{1}$, Stéphane Balayssac ${ }^{1}$, Nathalie Martins-Froment ${ }^{2}$, \\ Véronique Gilard ${ }^{1}{ }^{\mathbb{D}}$, Robert Martino ${ }^{1}$ and Myriam Malet-Martino ${ }^{1, *}$ \\ 1 Biomedical NMR Group, Laboratoire SPCMIB, UMR CNRS 5068, Université Paul Sabatier, 118 route de \\ Narbonne, 31062 Toulouse CEDEX 9, France; Rabab.Hachem@evotec.com (R.H.); \\ gaetan-ass@hotmail.fr (G.A.); balayssac@chimie.ups-tlse.fr (S.B.); gilard@chimie.ups-tlse.fr (V.G.); \\ rmartino@chimie.ups-tlse.fr (R.M.) \\ 2 Service commun de spectrométrie de masse, Institut de Chimie de Toulouse, Université Paul Sabatier, \\ 118 route de Narbonne, 31062 Toulouse CEDEX 9, France; martins@chimie.ups-tlse.fr \\ * Correspondence: martino@chimie.ups-tlse.fr; Tel.: +33-6-81-36-32-19
}

Academic Editor: Ping-Chung Kuo

Received: 9 November 2019; Accepted: 6 January 2020; Published: 13 January 2020

\begin{abstract}
Red yeast rice dietary supplements (RYR DS) are largely sold in Western countries for their cholesterol-lowering/regulating effect due to monacolins, mainly monacolin K (MK), which is, in fact, lovastatin, the first statin drug on the market. ${ }^{1} \mathrm{H}-\mathrm{NMR}$ was used as an easy, rapid and accurate method to establish the chemical profiles of 31 RYR DS and to quantify their monacolin contents. Among all the ${ }^{1} \mathrm{H}$ resonances of the monacolins found in RYR, only those of the ethylenic protons of the hexahydronaphthalenic ring at 5.84 and $5.56 \mathrm{ppm}$ are suitable for quantification because they show no overlap with the matrix signals. The total content in monacolins per capsule or tablet determined in 28 DS (the content in 3 DS being below the limit of quantification of the method, $\approx 0.25$ mg per unit dose) was close to that measured by UHPLC, as shown by the good linear correlation between the two sets of values (slope 1.00, y-intercept 0.113, $\mathrm{r}^{2}$ 0.986). Thirteen of the 31 RYR DS analyzed (i.e., $42 \%$ ) did not provide label information on the concentration of monacolins and only nine of the 18 formulations with an indication (i.e., 50\%) actually contained the declared amount of monacolins.
\end{abstract}

Keywords: red yeast rice; ${ }^{1} \mathrm{H}-\mathrm{NMR}$; UHPLC-DAD-MS; mass spectrometry; monacolins

\section{Introduction}

The Monascus-fermented rice is the fermentation product of non-glutinous white rice with the fungus Monascus. It has been used for more than a thousand years in East Asian countries for producing rice wine, for flavoring, coloring and preservation of foods as well as a folk medicine for improving food digestion and blood circulation. Several species other than that isolated in 1895 and named Monascus purpureus in recognition of its purple colour, have also been widely used in making red wine and red-coloured foods [1]. These Monascus fermentation products are called Red Yeast Rice (RYR) in Western countries although the designation "yeast" is incorrect as Monascus is a filamentous fungus and not a yeast [2]. Other more accurate denominations like red fermented rice or red mold rice are also used but much more rarely. Today, the usage of Monascus rice products as colorant or flavour in foods, and for brewing red rice wine is permitted in many Asian countries but not in Europe. However, RYR extracts are largely sold in Western countries for their cholesterol-lowering effects.

A multitude of fungal secondary metabolites, phytosterols, isoflavonoids, fatty acids, pigments, monacolins and others, are produced during the fermentation process. Monacolins, in particular 
monacolin $\mathrm{K}(\mathrm{MK})$, which is, in fact, lovastatin, the first marketed statin drug, inhibit the activity of 3-hydroxy-3-methylglutaryl coenzyme A (HMG-CoA) reductase. As a result, the endogenous synthesis of cholesterol is reduced and hence the elevated cholesterol level decreases. Many clinical studies demonstrated the efficacy of RYR in the treatment of hypercholesterolemia and its relative safety $[3,4]$. For similar cholesterol level reduction, the MK amount in clinically tested RYR is markedly lower than that used with prescription statin drugs [4]. This RYR potency is likely explained by the presence of monacolins other than MK and also by the improved dissolution rate and bioavailability of lovastatin when given as RYR [4,5]. However, adverse effects following RYR consumption have been reported; the nature of the symptoms and the targeted organs and systems are similar to those reported for statin drugs [6-9]. Considering the case reports gathered in the WHO Vigibase (82) [8] and those collected by four national health institutions (FDA (164) [8], French Nutrivigilance system (30) [6], Italian Surveillance system (52) [7] and Netherlands Pharmacovigilance Centre Lareb (74) [9]), the more frequent adverse effects are: (i) myalgias and related neuroskeletal complaints from 30\% of FDA cases to $43 \%$ of Lareb cases, including cases of rhabdomyolysis in the five registries, (ii) gastrointestinal disorders which concern up to $23 \%$ of Italian cases, (iii) hepatobiliary disorders that affect from $9 \%$ of the WHO cases to $32 \%$ of the French cases, including severe adverse reactions as pancreatitis and acute hepatic failure, and (iv) skin and subcutaneous disorders which concern from $8 \%$ of French cases to $17 \%$ of Italian cases.

Nowadays, RYR is widely used as a cholesterol-lowering agent by patients with a proven or perceived intolerance to statins or by consumers, even without dyslipidemia or increased cardiovascular risk, interested in complementary and alternative medications to influence their lipid levels, as it is a common belief that "natural" products do not have side effects [4]. The RYR products are registered as dietary supplements (DS) and, despite their ever growing popularity, there is no uniform regulation regarding their content in monacolins, especially in $\mathrm{MK}$, nor strict quality control. So, their efficacy and safety are unpredictable. Therefore, the development of analytical methods for the simultaneous determination of MK and other monacolins in RYR products is of great importance.

High performance or Ultra-high performance liquid chromatography (HPLC or UHPLC) with diode array detection (DAD) and/or mass spectrometry (MS) detection are regarded as the gold standard methods for the accurate identification and quantification of a wide range of components in RYR products, including monacolins and pigments [10-14]. Although sensitive and selective, they are usually time-consuming, require standard reference materials for quantitative analysis and may suffer from the occurrence of co-eluting interferences (matrix effects) which is a major drawback for MS quantification [15]. Proton Nuclear Magnetic Resonance $\left({ }^{1} \mathrm{H}-\mathrm{NMR}\right)$ is recognized as a method of choice for the analysis of complex mixtures (pharmaceuticals, biological media for instance) [16,17]. Indeed, it is highly reproducible, robust, and nonselective, thus allowing an unbiased overview of the sample composition as all the low molecular weight compounds in the solution (provided they bear ${ }^{1} \mathrm{H}$ nuclei and are present at sufficient concentration) are detected simultaneously in a single run. It is also inherently quantitative because the area of each NMR resonance is directly proportional to the number of corresponding nuclei if spectra are recorded in fully relaxed conditions. Thus, at variance with other techniques, the response factor is not dependent on the molecular structure and there is no need for identical reference materials. Moreover, the sample preparation for NMR analysis is very simple as it requires dissolution (for solid products) or dilution (for liquid products) in an adequate deuterated solvent [16]. Lachenmeyer et al. [18] have already used ${ }^{1} \mathrm{H}-\mathrm{NMR}$ for the assay of the total quantity of monacolins in five RYR commercial products. They showed that the inhibitory effect of RYR on HMG-CoA reductase was all the more important as their monacolin content was high, but the monacolin contents they determined were not compared to those measured by an orthogonal analytical method.

The purpose of this study was to validate (or not) the ${ }^{1} \mathrm{H}-\mathrm{NMR}$ method for an accurate determination of the monacolin content in RYR DS by comparison with the well-established HPLC method and thus to control their quality. Therefore, 31 RYR DS were analyzed using ${ }^{1} \mathrm{H}-\mathrm{NMR}$ to 
establish their spectral signatures and to determine their monacolin contents based on the quantification of selected protons characteristic of the different monacolin chemical structures usually present. An UHPLC analysis with UV-Visible (UV-Vis) and MS detection was performed in parallel on the same 31 RYR DS in order to determine their chemical profiles and to quantify all the monacolins identified.

\section{Results and Discussion}

\section{1. ${ }^{1} \mathrm{H}-\mathrm{NMR}$ Analysis}

Thirty-one RYR DS were analyzed by ${ }^{1} \mathrm{H}-\mathrm{NMR}$. All samples with their name, origin, form, batch number, expiration date and RYR extract content are listed in Table 1.

\subsubsection{Qualitative ${ }^{1} \mathrm{H}-\mathrm{NMR}$ Analysis}

Four characteristic spectra are illustrated in Figure 1 (the ${ }^{1} \mathrm{H}-\mathrm{NMR}$ spectra of all RYR DS analyzed are shown in Figure S1). The monacolin resonances were identified by comparing the ${ }^{1} \mathrm{H}-\mathrm{NMR}$ spectra of RYR DS with those of standard monacolins whose chemical structures are respectively characteristic of monacolins in lactone form (MK and compactin (CP)), monacolins in hydroxyl acid form (MKA), dehydromonacolins (DeMK) and dihydromonacolins (DiMK), the main monacolin derivatives found in RYR (see Figure 2 for chemical structures) [10,12,13]. Their ${ }^{1} \mathrm{H}-\mathrm{NMR}$ assignments are given in Table 2. A complete one-dimensional (1D) and two-dimensional (2D) description of the ${ }^{1} \mathrm{H}$ and ${ }^{13} \mathrm{C}-\mathrm{NMR}$ signals of standard MK, MKA, CP and DiMK is presented in Table S1.

The resonances of the hexahydronaphthalene ring ethylenic protons ( $\mathrm{H} 5, \mathrm{H} 6, \mathrm{H} 4$ at $\approx 6.01,5.84$ and $5.56 \mathrm{ppm}$, respectively) are representative of all the monacolins usually found in RYR, except dihydromonacolins as the $\delta$ of the ethylenic protons $\mathrm{H} 5$ and $\mathrm{H} 6$ of DiMK resonated at 5.42 and 5.69 ppm, respectively (Figures 1 and 3, Table 2 ). The $\mathrm{H} 1$ signal $(\mathrm{q})$ at $\approx 5.33$ ppm is characteristic of monacolins with a hexahydronaphthalene ring and an ester group (O-CO-R) in position 1. Indeed, for the monacolins with an $\mathrm{OH}$ (monacolin $\mathrm{J}(\mathrm{MJ})$ and derivatives) or H substituent (monacolin L (ML) and derivatives) instead of ester (Figure 2 ), the $\mathrm{H} 1$ proton(s) resonated respectively at $\approx 4.24 \mathrm{ppm}$ or 1.17 and $1.77 \mathrm{ppm}[1,19]$. The $\mathrm{H} 20$ multiplet at $\approx 4.60 \mathrm{ppm}$ is characteristic of all the monacolins in lactone form including dihydromonacolins but not of monacolins in hydroxyl acid form and dehydromonacolins (Table 2, Figure 3). The H22 signal at $\approx 4.25 \mathrm{ppm}$ is also characteristic of all the monacolins in lactone form (Table 2, Figure 3).

All these monacolin resonances mainly arise from MK, the main monacolin present in RYR DS [1] but other characteristic signals of monacolins were also identified: dehydromonacolins (H22 at $7.03 \mathrm{ppm}$ ), dihydromonacolins (H6 at $5.69 \mathrm{ppm}$ ) and monacolins in hydroxyl acid form (H22 at 4.05 ppm and $\mathrm{H} 20$ at 3.63 ppm) (Figure $1 \mathrm{~B}$ for some signals).

The singlet of the $\mathrm{H} 1$ of citrinin at $5.94 \mathrm{ppm}$ and $8.45 \mathrm{ppm}$ (see footnote 4 of Table 2 for explanation) was never observed, which is not surprising due to the expected very low amount of this compound even if it could have been present [12,13].

Beside the assignments of the different monacolin families, ${ }^{1} \mathrm{H}$ characteristic signals of many other compounds mentioned or not on the label of the RYR DS were detected (Table 2). Fatty acids, both saturated (SFA) and non-conjugated unsaturated (UFA), were found in all the formulations (Figure 1 and Table 3 ) as it has been reported that they represent $\approx 3 \%$ of RYR extracts, each group in approximately identical proportion $(\approx 1.4 \%)[1]$. The presence of glycerol and glucose was observed in 25 and 24 samples, respectively. The singlet at $\approx 5.50 \mathrm{ppm}$ characteristic of the $\mathrm{H} 4$ of monascin and/or other pigments with the same skeleton (ankaflavin, monascuspiloin, monaphilones A or B) (Figure 2) was observed in 20 formulations. Some other compounds, generally mentioned on the label of the RYR DS, were detected in few samples: sorbitol and piperine in two samples as well as carnitine, vitamin B3, vitamin C, chlorogenic acid and isopropyl alcohol in one sample (Tables 2 and 3). 
Table 1. Red Yeast Rice (RYR) dietary supplements investigated in this study.

\begin{tabular}{|c|c|c|c|c|c|}
\hline \multirow{2}{*}{$\begin{array}{c}\text { Number } \\
1\end{array}$} & \multirow{2}{*}{$\begin{array}{c}\begin{array}{c}\text { Formulation } \\
\text { Name (Origin }\end{array}{ }^{\mathbf{1}} \text { ) } \\
\begin{array}{c}\text { Arkopharma } \\
\text { (HFS) }\end{array}\end{array}$} & \multicolumn{2}{|c|}{$\begin{array}{l}\text { Batch Number } \\
\text { Expiration Date }\end{array}$} & \multirow{2}{*}{$\begin{array}{c}\text { Form } \\
\text { Capsule }\end{array}$} & \multirow{2}{*}{$\begin{array}{c}\text { RYR Extract Content } \\
\text { Per Capsule or Tablet } \\
\text { on the Label (mg) }\end{array}$} \\
\hline & & C02194A & 04/2016 & & \\
\hline 2 & Arterin (I) & 1983-1 & $07 / 2016$ & Tablet & 670 \\
\hline 3 & B.concept (I) & 13DN8 & 09/2016 & Capsule & 186 \\
\hline 4 & Belle \& Bio (I) & B524A & $06 / 2015$ & Capsule & 250 \\
\hline 5 & Blue bonnet (I) & 31201702 & 01/2017 & Capsule & 600 \\
\hline 6 & $\begin{array}{l}\text { Boutique nature } \\
\text { (I) }\end{array}$ & $32443 \mathrm{~A}$ & $03 / 2016$ & Capsule & 222.3 \\
\hline 7 & Doctor's best (I) & ML847 & 01/2017 & Tablet & 1200 \\
\hline 8 & Ephyto (I) & B1204059CZ & $01 / 2015$ & Tablet & 600 \\
\hline 9 & Fushi (I) & EPAN110412 & 08/2015 & Capsule & 600 \\
\hline 10 & Hanoju (I) & 20130612 & $06 / 2016$ & Capsule & 450 \\
\hline 11 & Health Ace (I) & 106012W9 & 03/2015 & Capsule & 650 \\
\hline 12 & Health Spark (I) & 1060012/A1 & 10/2014 & Capsule & 650 \\
\hline 13 & Liposterol (HFS) & 03023 & $05 / 2016$ & Tablet & 600 \\
\hline 14 & MRM (I) & 130736 & $08 / 2016$ & Capsule & 600 \\
\hline 15 & Nat et form (I) & 14387J & $10 / 2016$ & Capsule & 600 \\
\hline 16 & Natrol (I) & 2055200 & $10 / 2015$ & Tablet & 400 \\
\hline 17 & Nature algues (I) & $\begin{array}{l}\text { G0112112602 } \\
\text { PF01G }\end{array}$ & $11 / 2016$ & Capsule & 250 \\
\hline 18 & Nature's plus (I) & 1249540 & 09/2016 & Tablet & 600 \\
\hline 19 & Nature's way (I) & 20012472 & $05 / 2016$ & Capsule & 600 \\
\hline 20 & Naturland (HFS) & C02196A & $04 / 2016$ & Capsule & 175 \\
\hline 21 & Now (I) & 16117750521 & $06 / 2015$ & Capsule & 600 \\
\hline 22 & Nutrisanté (I) & 961PAA & $05 / 2016$ & Capsule & 222.2 \\
\hline 23 & $\begin{array}{l}\text { Pharma nature } \\
\text { (HFS) }\end{array}$ & 1009.211 & $12 / 2014$ & Capsule & 300 \\
\hline 24 & $\begin{array}{l}\text { Phytalessence } \\
\text { (HFS) }\end{array}$ & 10134 & $10 / 2016$ & Tablet & 600 \\
\hline 25 & Phytoreponse (I) & B1210229CZ & $10 / 2015$ & Tablet & 600 \\
\hline 26 & Rizocol (I) & 9545 & $06 / 2016$ & Tablet & 335 \\
\hline 27 & Santé verte (HFS) & L066X2 & 03/2016 & Tablet & 600 \\
\hline 28 & Solaray (I) & 171306 & $12 / 2016$ & Capsule & 600 \\
\hline 29 & Solgar (I) & 747369-02 & 07/2016 & Capsule & 600 \\
\hline 30 & $\begin{array}{l}\text { Tradition soleil } \\
\text { levant (I) }\end{array}$ & 89853 & 07/2016 & Capsule & 208 \\
\hline 31 & 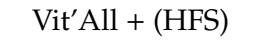 & A7248-11 & $11 / 2013$ & Tablet & 600 \\
\hline
\end{tabular}

${ }^{1}$ Dietary supplements bought on internet web sites (I) or in health food stores (HFS). 
(A)

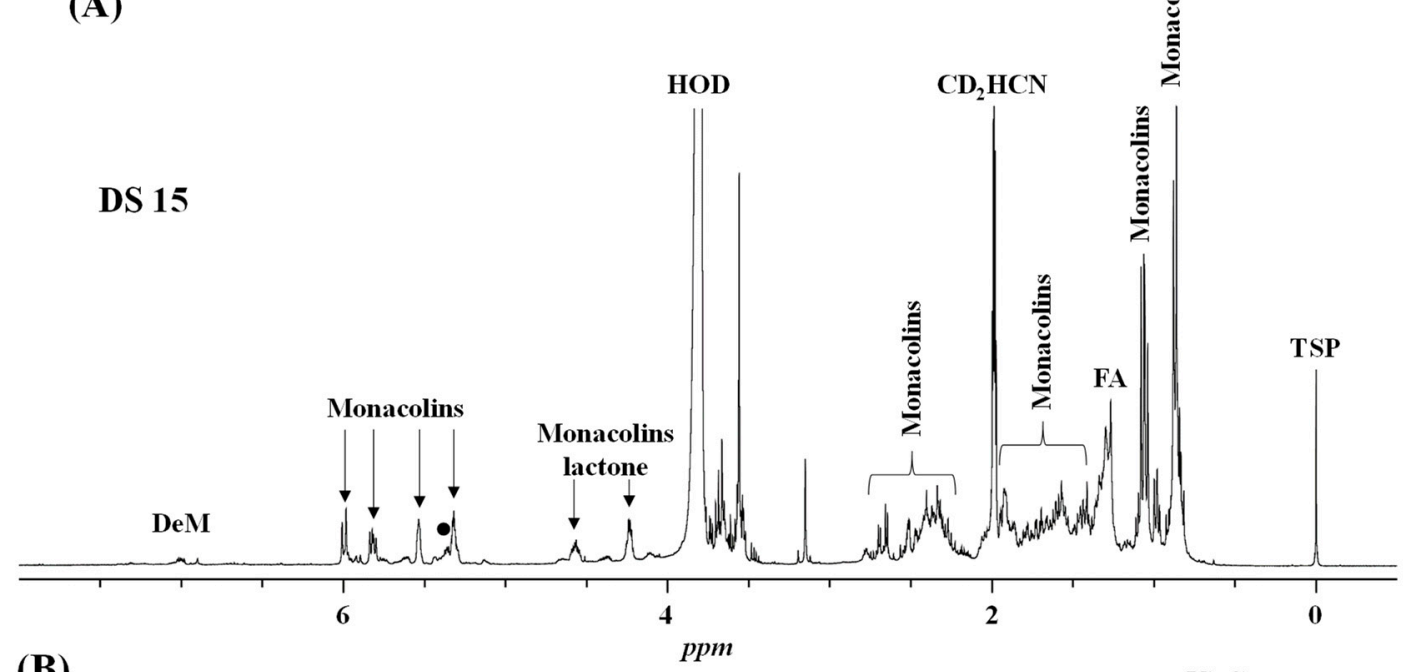

(B)

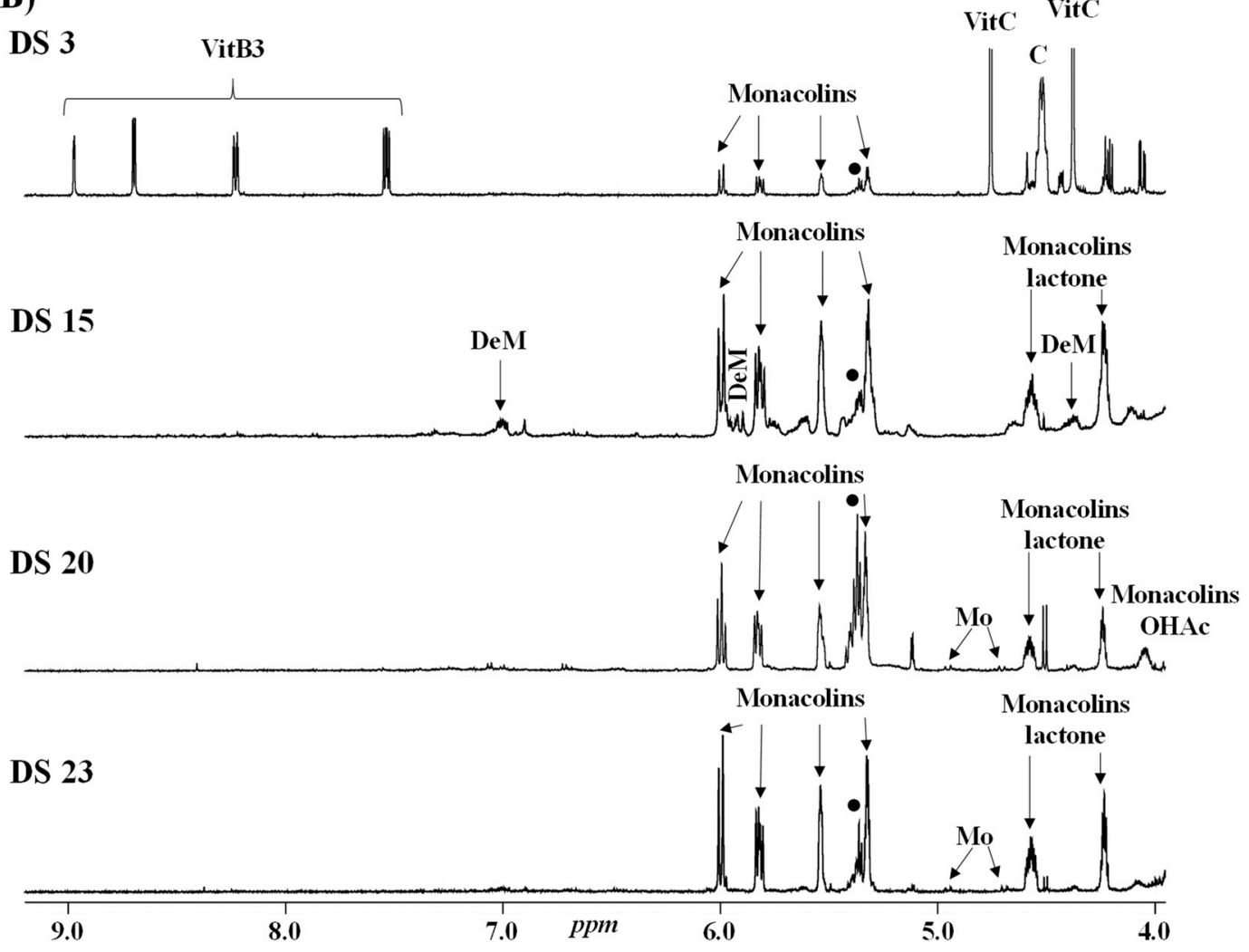

Figure 1. ${ }^{1} \mathrm{H}-\mathrm{NMR}$ spectra of selected RYR dietary supplements (DS) recorded in $\mathrm{CD}_{3} \mathrm{CN}: \mathrm{D}_{2} \mathrm{O}(80: 20)$. Entire spectrum of DS 15 (A) and enlarged downfield region (4-9 ppm) (B) of the DS 3, 15, 20 and 23. DeM: dehydromonacolins, Monacolins lactone: monacolins in lactone form, Monacolins OHAc: monacolins in hydroxyl acid form, Mo: monascin and other pigments with the same skeleton, FA: fatty acids (saturated and unsaturated), $\bullet$ : non-conjugated unsaturated fatty acids, C: carnitine, Vit: vitamin, TSP: sodium 2,2,3,3-tetradeutero-3-(trimethylsilyl) propanoate, set at $0 \mathrm{ppm}$. 


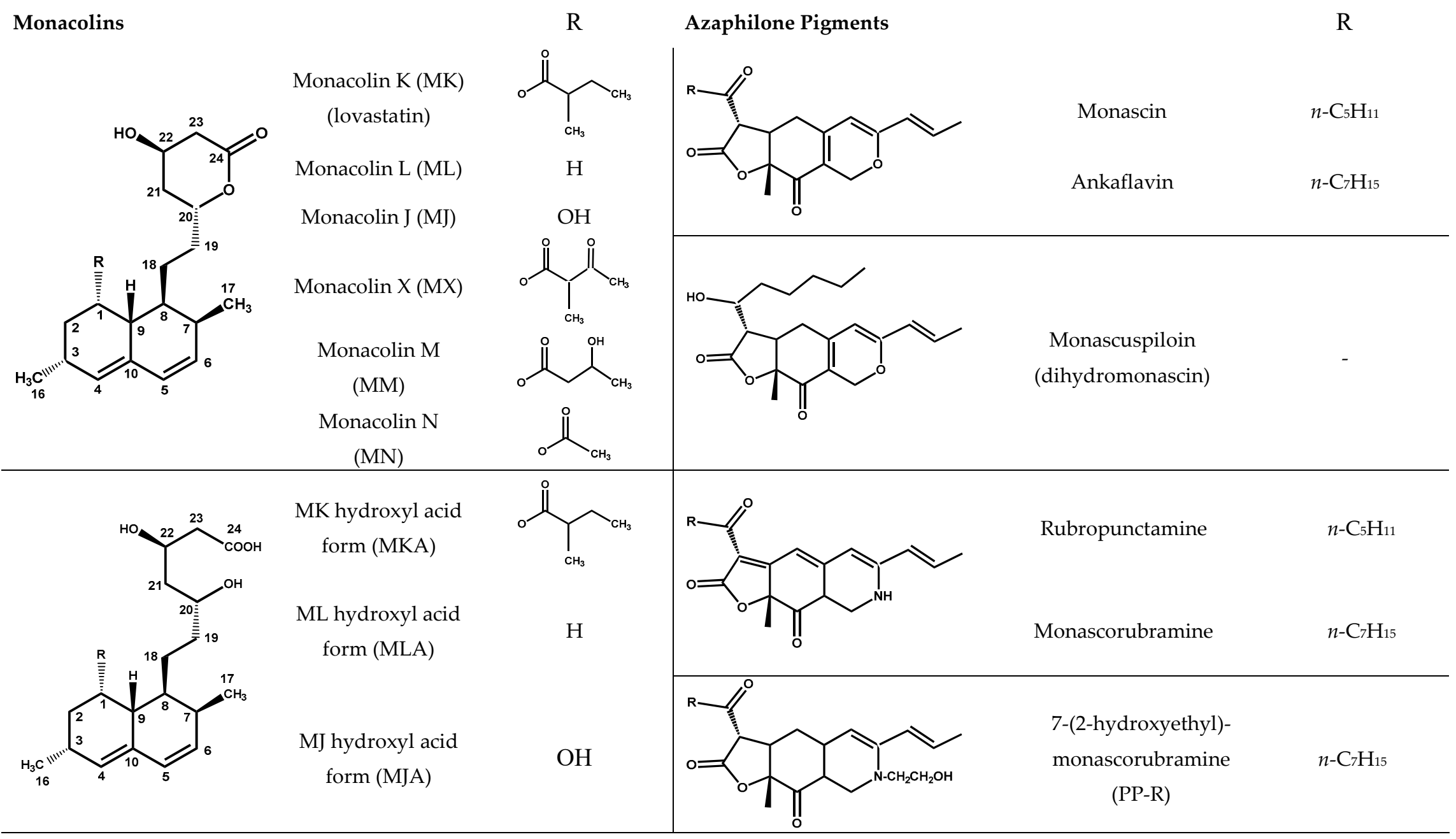

Figure 2. Cont. 


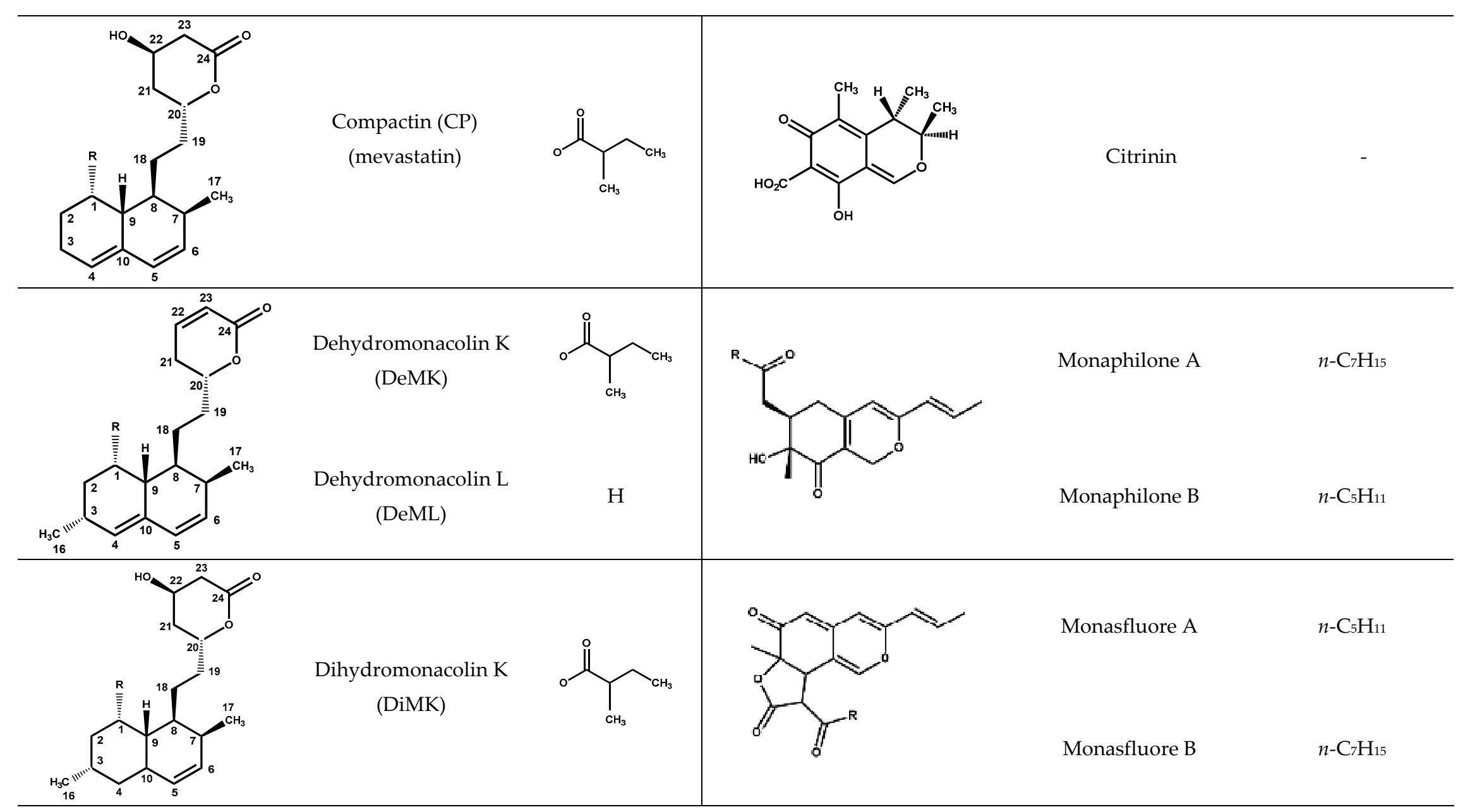

Figure 2. Chemical structures of monacolins and pigments discussed in this study. 
Table 2. Structures and ${ }^{1} \mathrm{H}-\mathrm{NMR}$ characteristics (solvent: $\mathrm{CD}_{3} \mathrm{CN}: \mathrm{D}_{2} \mathrm{O} 80: 20$ ) of standard monacolins and other compounds identified in this study.

\begin{tabular}{|c|c|c|}
\hline \multirow{2}{*}{ Compound } & \multirow{2}{*}{ Structure } & ${ }^{1}{ }_{H}-N M R{ }^{1}$ \\
\hline & & $\delta(\mathrm{ppm})$ (Multiplicity ${ }^{2}, J(\mathrm{~Hz})$, Number of Protons, Attribution) \\
\hline $\begin{array}{l}\text { Monacolin K lactone } \\
\text { form (MK) }\end{array}$ & & $\begin{array}{l}6.01(\mathrm{~d}, J=9.6,1 \mathrm{H}, \mathrm{H}-5), 5.84(\mathrm{dd}, J=6.1,9.6,1 \mathrm{H}, \mathrm{H}-6), 5.56(\mathrm{app} \mathrm{t}, J=2.8,1 \mathrm{H}, \mathrm{H}-4), 5.35(\mathrm{q}, J=3.2,1 \mathrm{H}, \\
\mathrm{H}-1), 4.59(\mathrm{~m}, 1 \mathrm{H}, \mathrm{H}-20), 4.25(\text { app quint } J=3.9,1 \mathrm{H}, \mathrm{H}-22), 2.69(\mathrm{Ad}, J=4.9,17.6,1 \mathrm{H}, \mathrm{H}-23), 2.51(\mathrm{Bdd}, \\
J=1.7,3.8,17.6,1 \mathrm{H}, \mathrm{H}-23), 2.45(\mathrm{~m}, 1 \mathrm{H}, \mathrm{H}-3), 2.42(\mathrm{~m}, 1 \mathrm{H}, \mathrm{H}-7), 2.37(\mathrm{~m}, 1 \mathrm{H}, \mathrm{H}-9), 2.35(\mathrm{~m}, 1 \mathrm{H}, \mathrm{H}-12), \\
1.96(\mathrm{~m}, 2 \mathrm{H}, \mathrm{H}-2), 1.90 \text { and } 1.71(\mathrm{two} \mathrm{m}, 2 \mathrm{H}, \mathrm{H}-21), 1.81 \text { and } 1.37(\mathrm{two} \mathrm{m}, 2 \mathrm{H}, \mathrm{H}-19), 1.69(\mathrm{~m}, 1 \mathrm{H}, \mathrm{H}-8), \\
1.62(\operatorname{app} \mathrm{qd}, J=7.4,13.6,1 \mathrm{H}, \mathrm{H}-13), 1.46(\mathrm{~m}, 2 \mathrm{H}, \mathrm{H}-13 \text { and } \mathrm{H}-18), 1.36(\mathrm{~m}, 1 \mathrm{H}, \mathrm{H}-18), 1.08(\mathrm{~d}, J=6.9,3 \mathrm{H}, \\
\mathrm{H}-15), 1.06(\mathrm{~d}, J=7.4,3 \mathrm{H}, \mathrm{H}-16), 0.89(\mathrm{~d}, J=6.9,3 \mathrm{H}, \mathrm{H}-17), 0.88(\mathrm{t}, J=7.5,3 \mathrm{H}, \mathrm{H}-14)\end{array}$ \\
\hline $\begin{array}{l}\text { Monacolin K hydroxyl } \\
\text { acid form (MKA) }\end{array}$ & & $\begin{array}{l}5.99(\mathrm{~d}, J=9.6,1 \mathrm{H}, \mathrm{H}-5), 5.83(\mathrm{dd}, J=6.1,9.6,1 \mathrm{H}, \mathrm{H}-6), 5.53(\mathrm{app} \mathrm{t}, J=2.8,1 \mathrm{H}, \mathrm{H}-4), 5.33(\mathrm{q}, J=3.2,1 \mathrm{H}, \\
\mathrm{H}-1), 4.05(\mathrm{~m}, 1 \mathrm{H}, \mathrm{H}-22), 3.63(\mathrm{app} \text { hept }, J=4.1,1 \mathrm{H}, \mathrm{H}-20), 2.42(\mathrm{~m}, 1 \mathrm{H}, \mathrm{H}-3), 2.39(\mathrm{~m}, 1 \mathrm{H}, \mathrm{H}-7), 2.35(\mathrm{~m}, \\
1 \mathrm{H}, \mathrm{H}-9), 2.33(\mathrm{~m}, 2 \mathrm{H}, \mathrm{H}-12 \text { and H-23), } 2.16(\mathrm{dd}, J=8.7,15.2,1 \mathrm{H}, \mathrm{H}-23), 1.93(\mathrm{~m}, 2 \mathrm{H}, \mathrm{H}-2), 1.63(\mathrm{~m}, 1 \mathrm{H}, \\
\mathrm{H}-8), 1.59 \text { and } 1.45(\mathrm{two} \mathrm{m}, 2 \mathrm{H}, \mathrm{H}-13), 1.57 \text { and } 1.51(\mathrm{two} \mathrm{m}, 2 \mathrm{H}, \mathrm{H}-21), 1.53 \text { and } 1.15(\mathrm{two} \mathrm{m}, 2 \mathrm{H}, \mathrm{H}-19), \\
1.32(\mathrm{~m}, 2 \mathrm{H}, \mathrm{H}-18), 1.08(\mathrm{~d}, J=6.9,3 \mathrm{H}, \mathrm{H}-15), 1.05(\mathrm{~d}, J=7.4,3 \mathrm{H}, \mathrm{H}-16), 0.87(\mathrm{~d}, J=6.9,3 \mathrm{H}, \mathrm{H}-17), 0.86(\mathrm{t}, \\
J=7.4,3 \mathrm{H}, \mathrm{H}-14)\end{array}$ \\
\hline $\begin{array}{l}\text { Compactin }(\mathrm{CP})= \\
\text { Mevastatin }\end{array}$ & & $\begin{array}{l}6.00(\mathrm{~d}, J=9.7,1 \mathrm{H}, \mathrm{H}-5), 5.79(\mathrm{dd}, J=6.0,9.7,1 \mathrm{H}, \mathrm{H}-6), 5.57(\mathrm{~m}, 1 \mathrm{H}, \mathrm{H}-4), 5.30(\mathrm{~m}, 1 \mathrm{H}, \mathrm{H}-1), 4.60(\mathrm{~m}, 1 \mathrm{H}, \\
\mathrm{H}-20), 4.25(\text { app quint }, J=3.9,1 \mathrm{H}, \mathrm{H}-22), 2.69(\mathrm{Ad}, J=4.8,17.6,1 \mathrm{H}, \mathrm{H}-23), 2.51(\mathrm{Bdd}, J=1.7,3.6,17.6,1 \mathrm{H}, \\
\mathrm{H}-23), 2.42(\mathrm{~m}, 2 \mathrm{H}, \mathrm{H}-7 \text { and H-9), } 2.38(\mathrm{~m}, 1 \mathrm{H}, \mathrm{H}-12), 2.15(\mathrm{~m}, 2 \mathrm{H}, \mathrm{H}-3), 2.08(\mathrm{~m}, 1 \mathrm{H}, \mathrm{H}-2), 1.90(\mathrm{~m}, 1 \mathrm{H}, \\
\mathrm{H}-21), 1.81 \text { and } 1.37(\mathrm{two} \mathrm{m}, 2 \mathrm{H}, \mathrm{H}-19), 1.72(\mathrm{~m}, 2 \mathrm{H}, \mathrm{H}-2 \text { and H-21), } 1.68(\mathrm{~m}, 1 \mathrm{H}, \mathrm{H}-8), 1.62(\text { app qd, } \\
J=7.6,13.6,1 \mathrm{H}, \mathrm{H}-13), 1.48 \text { and } 1.39(\mathrm{two} \mathrm{m}, 2 \mathrm{H}, \mathrm{H}-18), 1.46(\mathrm{~m}, 1 \mathrm{H}, \mathrm{H}-13), 1.11(\mathrm{~d}, J=7.0,3 \mathrm{H}, \mathrm{H}-15), \\
0.90(\mathrm{~d}, J=7.0,3 \mathrm{H}, \mathrm{H}-17), 0.89(\mathrm{t}, J=7.5,3 \mathrm{H}, \mathrm{H}-14)\end{array}$ \\
\hline
\end{tabular}


Table 2. Cont

\begin{tabular}{|c|c|c|}
\hline \multirow{2}{*}{ Compound } & \multirow{2}{*}{ Structure } & ${ }^{1} \mathrm{H}-\mathrm{NMR}{ }^{1}$ \\
\hline & & $\delta(\mathrm{ppm})$ (Multiplicity ${ }^{2}, J(\mathrm{~Hz})$, Number of Protons, Attribution) \\
\hline $\begin{array}{l}\text { Dehydromonacolin K } \\
\text { (DeMK) }\end{array}$ & & $\begin{array}{l}7.03(\mathrm{ddd}, J=2.5,6.0,9.8,1 \mathrm{H}, \mathrm{H}-22), 6.02(\mathrm{~d}, J=9.6,1 \mathrm{H}, \mathrm{H}-5), 5.97(\mathrm{ddd}, J=1.0,2.7,9.8,1 \mathrm{H}, \mathrm{H}-23), 5.84 \\
(\mathrm{dd}, J=6.1,9.6,1 \mathrm{H}, \mathrm{H}-6), 5.56(\text { app t}, J=2.8,1 \mathrm{H}, \mathrm{H}-4), 5.33(\mathrm{q}, J=3.2,1 \mathrm{H}, \mathrm{H}-1), 4.42(\mathrm{~m}, 1 \mathrm{H}, \mathrm{H}-20), 2.44 \\
(\mathrm{~m}, 1 \mathrm{H}, \mathrm{H}-3), 2.43(\mathrm{~m}, 1 \mathrm{H}, \mathrm{H}-7), 2.42 \text { and } 2.30(\mathrm{two} \mathrm{m}, 2 \mathrm{H}, \mathrm{H}-21), 2.36(\mathrm{~m}, 1 \mathrm{H}, \mathrm{H}-9), 2.35(\mathrm{~m}, 1 \mathrm{H}, \mathrm{H}-12), \\
1.96(\mathrm{~m}, 2 \mathrm{H}, \mathrm{H}-2), 1.90 \text { and } 1.41(\mathrm{two} \mathrm{m}, 2 \mathrm{H}, \mathrm{H}-19), 1.70(\mathrm{~m}, 1 \mathrm{H}, \mathrm{H}-8), 1.62(\mathrm{app} \mathrm{qd}, J=7.5,13.8,1 \mathrm{H}, \\
\mathrm{H}-13), 1.46(\mathrm{~m}, 1 \mathrm{H}, \mathrm{H}-13), 1.45 \text { and } 1.39(\mathrm{two} \mathrm{m}, 2 \mathrm{H}, \mathrm{H}-18), 1.09(\mathrm{~d}, J=6.9,3 \mathrm{H}, \mathrm{H}-15), 1.07(\mathrm{~d}, J=7.4,3 \mathrm{H}, \\
\mathrm{H}-16), 0.89(\mathrm{~d}, J=6.9,3 \mathrm{H}, \mathrm{H}-17), 0.88(\mathrm{t}, J=7.5,3 \mathrm{H}, \mathrm{H}-14)\end{array}$ \\
\hline $\begin{array}{l}\text { Dihydromonacolin K } \\
\text { (DiMK) }\end{array}$ & & $\begin{array}{l}5.69(\mathrm{ddd}, J=2.7,5.0,9.8,1 \mathrm{H}, \mathrm{H}-6), 5.42(\mathrm{~d}, J=9.8,1 \mathrm{H}, \mathrm{H}-5), 5.15(\mathrm{q}, J=2.7,1 \mathrm{H}, \mathrm{H}-1), 4.58(\mathrm{~m}, 1 \mathrm{H}, \mathrm{H}-20), \\
4.25(\text { app quint } J=3.8,1 \mathrm{H}, \mathrm{H}-22), 2.68(\mathrm{Ad}, J=4.9,17.7,1 \mathrm{H}, \mathrm{H}-23), 2.50(\mathrm{Bdd}, J=1.7,3.7,17.7,1 \mathrm{H}, \mathrm{H}-23), \\
2.46(\mathrm{~m}, 1 \mathrm{H}, \mathrm{H}-10), 2.39(\mathrm{~m}, 1 \mathrm{H}, \mathrm{H}-12), 2.34(\mathrm{~m}, 1 \mathrm{H}, \mathrm{H}-7), 2.05(\mathrm{~m}, 1 \mathrm{H}, \mathrm{H}-3), 1.88 \text { and } 1.72(\mathrm{two} \mathrm{m}, 2 \mathrm{H}, \\
\mathrm{H}-21), 1.81 \text { and } 1.37(\mathrm{two} \mathrm{m}, 2 \mathrm{H}, \mathrm{H}-19), 1.80(\mathrm{~m}, 2 \mathrm{H}, \mathrm{H}-2), 1.66(\mathrm{~m}, 1 \mathrm{H}, \mathrm{H}-8), 1.64(\mathrm{~m}, 1 \mathrm{H}, \mathrm{H}-13), 1.61 \text { and } \\
1.35(\mathrm{two} \mathrm{m}, 2 \mathrm{H}, \mathrm{H}-4), 1.49(\mathrm{app} \mathrm{qd}, J=7.4,13.6,1 \mathrm{H}, \mathrm{H}-13), 1.35 \text { and } 1.30(\mathrm{two} \mathrm{m}, 2 \mathrm{H}, \mathrm{H}-18), 1.12(\mathrm{~d}, \\
J=7.0,3 \mathrm{H}, \mathrm{H}-15), 1.11(\mathrm{~d}, J=7.6,3 \mathrm{H}, \mathrm{H}-16), 0.90(\mathrm{t}, J=7.5,3 \mathrm{H}, \mathrm{H}-14), 0.86(\mathrm{~d}, J=7.0,3 \mathrm{H}, \mathrm{H}-17)\end{array}$ \\
\hline Monascin $^{3}$ & & $\begin{array}{l}6.50\left(\mathrm{qd}, J=7.0,15.5,1 \mathrm{H}, \mathrm{H}-2^{\prime}\right), 6.05\left(\mathrm{qd}, J=1.7,15.5,1 \mathrm{H}, \mathrm{H}-1^{\prime}\right), 5.51(\mathrm{~s}, 1 \mathrm{H}, \mathrm{H}-4), 4.97(\mathrm{At}, J=0.9,12.7, \\
1 \mathrm{H}, \mathrm{H}-1), 4.72(\mathrm{Bt}, J=1.4,12.7,1 \mathrm{H}, \mathrm{H}-1), 4.14(\mathrm{~d}, J=13.3,1 \mathrm{H}, \mathrm{H}-11), 3.15(\mathrm{~m}, 1 \mathrm{H}, \mathrm{H}-6), 2.88(\mathrm{At}, J=7.3, \\
18.2,1 \mathrm{H}, \mathrm{H}-13), 2.67(\mathrm{Bt}, J=7.3,18.2,1 \mathrm{H}, \mathrm{H}-13), 2.63(\mathrm{app} \text { br d}, J=7.7,2 \mathrm{H}, \mathrm{H}-5), 1.87(\mathrm{dd}, J=1.7,7.0,3 \mathrm{H}, \\
\left.\left.\mathrm{H}-3^{\prime}\right), 1.59 \text { (quint, } J=7.3,2 \mathrm{H}, \mathrm{H}-14\right), 1.43(\mathrm{~s}, 3 \mathrm{H}, \mathrm{H}-7), 1.32(\mathrm{~m}, 4 \mathrm{H}, \mathrm{H}-15, \mathrm{H}-16), 0.91(\mathrm{t}, J=7.2,3 \mathrm{H}, \mathrm{H}-17)\end{array}$ \\
\hline Citrinin $^{4}$ & & 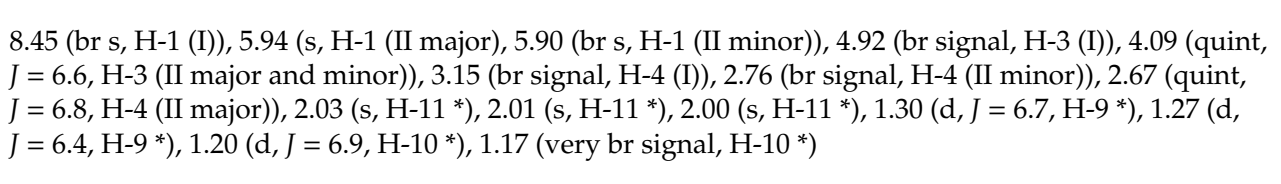 \\
\hline
\end{tabular}


Table 2. Cont.

\begin{tabular}{|c|c|c|}
\hline \multirow{2}{*}{ Compound } & \multirow{2}{*}{ Structure } & \multirow{2}{*}{$\begin{array}{c}{ }^{1} \mathrm{H}-\mathrm{NMR}{ }^{1} \\
\delta(\mathrm{ppm})\left(\text { Multiplicity }{ }^{2}, J(\mathrm{~Hz}), \text { Number of Protons, Attribution) }\right.\end{array}$} \\
\hline & & \\
\hline Piperine & & $\begin{array}{l}7.28(\mathrm{ddd}, J=2.7,7.3,14.7,1 \mathrm{H}, \mathrm{H}-9), 7.11(\mathrm{~d}, J=1.6,1 \mathrm{H}, \mathrm{H}-20), 6.99(\mathrm{dd}, J=1.7,8.1,1 \mathrm{H}, \mathrm{H}-13), 6.87(\mathrm{~d}, \\
J=8.0,1 \mathrm{H}, \mathrm{H}-14), 6.83(\mathrm{~m}, 2 \mathrm{H}, \mathrm{H}-10, \mathrm{H}-11), 6.60(\mathrm{~d}, J=14.7,1 \mathrm{H}, \mathrm{H}-8), 6.00(\mathrm{~s}, 2 \mathrm{H}, \mathrm{H}-17), 3.55(\mathrm{~m}, 4 \mathrm{H}, \mathrm{H}-2, \\
\mathrm{H}-6), 1.65(\mathrm{~m}, 2 \mathrm{H}, \mathrm{H}-4), 1.56(\mathrm{~m}, 4 \mathrm{H}, \mathrm{H}-3, \mathrm{H}-5)\end{array}$ \\
\hline Carnitine & & $4.56(\mathrm{br} \mathrm{q}, J=7.1,1 \mathrm{H}, \mathrm{CH}-\mathrm{OH}), 3.39\left(\mathrm{~m}, 2 \mathrm{H}, \mathrm{CH}_{2}-\mathrm{N}^{+}\right), 3.17\left(\mathrm{~s}, 9 \mathrm{H},\left(\mathrm{CH}_{3}\right)_{3}-\mathrm{N}^{+}\right), 2.58\left(\mathrm{~m}, 2 \mathrm{H}, \mathrm{CH}_{2}-\mathrm{COO}^{-}\right)$ \\
\hline Chlorogenic acid & & $\begin{array}{l}7.61(\mathrm{~d}, J=15.9,1 \mathrm{H}, \mathrm{H}-6), 7.16(\mathrm{~d}, J=2.0,1 \mathrm{H}, \mathrm{H}-1), 7.06(\mathrm{dd}, J=2.0,8.2,1 \mathrm{H}, \mathrm{H}-5), 6.88(\mathrm{~d}, J=8.2,1 \mathrm{H}, \\
\mathrm{H}-4), 6.34(\mathrm{~d}, J=15.9,1 \mathrm{H}, \mathrm{H}-7), 5.28(\mathrm{ddd}, J=4.6,9.4,10.5,1 \mathrm{H}, \mathrm{H}-9), 4.18(\mathrm{app} \mathrm{q}, J=3.5,1 \mathrm{H}, \mathrm{H}-10), 3.75 \\
(\mathrm{dd}, J=3.2,9.4,1 \mathrm{H}, \mathrm{H}-11), 2.26-1.97(\mathrm{~m}, 4 \mathrm{H}, \mathrm{H}-12, \mathrm{H}-14)\end{array}$ \\
\hline Saturated fatty acids & & $\begin{array}{l}2.20\left(\mathrm{t}, J=7.5,2 \mathrm{H}, \mathrm{CH}_{2}-\mathrm{COOH}\right), 1.59\left(\mathrm{~m}, 2 \mathrm{H}, \mathrm{CH}_{2}-\mathrm{CH}_{2}-\mathrm{COOH}\right), 1.30\left(\mathrm{~m}, 2 \mathrm{nH},\left(\mathrm{CH}_{2}\right) \mathrm{n}\right), 0.90(\mathrm{t}, J=6.3, \\
\left.3 \mathrm{H}, \mathrm{CH}_{3}\right)\end{array}$ \\
\hline$\alpha / \beta$ Glucose & & $\begin{array}{l}5.14(\mathrm{~d}, J=3.7,1 \mathrm{H}, \mathrm{H}-1 \alpha), 4.52(\mathrm{~d}, J=7.9,1 \mathrm{H}, \mathrm{H}-1 \beta), 3.85-3.60(\mathrm{~m}, 7 \mathrm{H}, \mathrm{H}-3 \alpha, \mathrm{H}-4 \alpha / \beta, \mathrm{H}-6 \alpha / \beta), 3.45-3.28 \\
(\mathrm{~m}, 4 \mathrm{H}, \mathrm{H}-2 \alpha, \mathrm{H}-3 \beta, \mathrm{H}-5 \alpha / \beta), 3.15(\mathrm{t}, J=8.5,1 \mathrm{H}, \mathrm{H}-2 \beta)\end{array}$ \\
\hline
\end{tabular}


Table 2. Cont.

\begin{tabular}{|c|c|c|}
\hline \multirow{2}{*}{ Compound } & \multirow{2}{*}{ Structure } & ${ }^{1} \mathrm{H}_{-N M R}{ }^{1}$ \\
\hline & & $\delta(\mathrm{ppm})\left(\right.$ Multiplicity ${ }^{2}, J(\mathrm{~Hz})$, Number of Protons, Attribution) \\
\hline Glycerol & & $3.66(\mathrm{tt}, J=4.6,6.3,1 \mathrm{H}, \mathrm{CH}), 3.55\left(\mathrm{Ad}, J=4.6,11.5,2 \mathrm{H}, \mathrm{CH}_{2}\right), 3.48\left(\mathrm{Bd}, J=6.2,11.5, \mathrm{CH}_{2}\right)$ \\
\hline Isopropyl alcohol & & $3.93($ hept $, J=6.1,1 \mathrm{H}, \mathrm{CH}), 1.14\left(\mathrm{~d}, J=6.1,6 \mathrm{H}, \mathrm{CH}_{3}\right)$ \\
\hline Linoleic acid ${ }^{5}$ & & $\begin{array}{l}5.36(\mathrm{~m}, 4 \mathrm{H}, \mathrm{H}-9, \mathrm{H}-10, \mathrm{H}-12, \mathrm{H}-13), 2.78(\mathrm{t}, J=6.7,2 \mathrm{H}, \mathrm{H}-11), 2.27(\mathrm{t}, J=7.5,2 \mathrm{H}, \mathrm{H}-2), 2.06(\mathrm{~m}, 4 \mathrm{H}, \mathrm{H}-8, \\
\mathrm{H}-14), 1.56(\mathrm{~m}, 2 \mathrm{H}, \mathrm{H}-3), 1.40-1.27(\mathrm{~m}, 14 \mathrm{H}, \mathrm{H}-4, \mathrm{H}-5, \mathrm{H}-6, \mathrm{H}-7, \mathrm{H}-15, \mathrm{H}-16, \mathrm{H}-17), 0.89(\mathrm{t}, J=6.8, \\
\text { 3H, H-18) }\end{array}$ \\
\hline Sorbitol & & $3.82-3.54(\mathrm{~m}, 8 \mathrm{H})$ \\
\hline $\begin{array}{l}\text { Vitamin B3 } \\
\text { (niacinamide form) }\end{array}$ & & $\begin{array}{l}8.99(\mathrm{~d}, J=2.3,1 \mathrm{H}, \mathrm{H}-2), 8.72(\mathrm{dd}, J=4.9,1.6,1 \mathrm{H}, \mathrm{H}-6), 8.25(\mathrm{td}, J=8.0,1.9,1 \mathrm{H}, \mathrm{H}-4), 7.56(\mathrm{dd}, J=8.0,4.9, \\
1 \mathrm{H}, \mathrm{H}-5)\end{array}$ \\
\hline Vitamin C & & $\begin{array}{l}4.76\left(\mathrm{~d}, \mathrm{X} \text { part of an } \mathrm{ABMX} \text { system, } \mathrm{J}_{\mathrm{XM}}=2.0,1 \mathrm{H}, \mathrm{CH}-\mathrm{O}-\right), 3.94(\mathrm{td}, \mathrm{M} \text { part of an } \mathrm{ABMX} \text { system, } \\
\left.J_{\mathrm{MX}}=1.9, J_{\mathrm{MA}}=J_{\mathrm{MB}}=6.6,1 \mathrm{H}, \mathrm{CH}-\mathrm{OH}\right), 3.66\left(\mathrm{AB} \text { part of an } \mathrm{ABMX} \text { system, } J_{\mathrm{AB}}=11.3, J_{\mathrm{AM}}=J_{\mathrm{BM}}=6.6,\right. \\
\left.2 \mathrm{H}, \mathrm{CH}_{2}-\mathrm{OH}\right)\end{array}$ \\
\hline
\end{tabular}

${ }^{1}$ The assignments of ${ }^{1} \mathrm{H}-\mathrm{NMR}$ signals of monacolins, citrinin, and monascin were in agreement with the literature data even if the solvents were different: $\mathrm{CDCl}{ }_{3}$ for $\mathrm{MK}, \mathrm{MKA}, \mathrm{CP}, \mathrm{DeMK}$ DiMK and citrinin [1,20-24], DMSO-d6 for monascin [25] and $\mathrm{D}_{2} \mathrm{O}$ for citrinin [22]. ${ }^{2} \mathrm{~d}$ : doublet, dd: doublet of doublet, ddd: doublet of doublet of doublet, $\mathrm{t}$ : triplet, td: doublet of triplet, $\mathrm{tt}$ triplet of triplet, q: quadruplet, qd: doublet of quadruplet, quint: quintuplet, hept: heptuplet, m: multiplet, A: part A of an AB system, B: part B of an AB system, app: apparent, br: broad. ${ }^{3} \mathrm{H} 11$ is exchanged with D and its resonance disappears rapidly with time as well as its coupling with $\mathrm{H} 6$ whose multiplet becomes a triplet $(J=7.9 \mathrm{~Hz}) .{ }^{4}$ The attributions were done according to the literature [22]. Citrinin exists as the quinone methide (I) in organic NMR solvents but as a diastereoisomeric mixture of hydrates (II) in aqueous solution at physiological pH, one diastereoisomer being major and the other minor. As the solvent used in the present study is a $\mathrm{CD}_{3} \mathrm{CN}_{\mathrm{N}} \mathrm{D}_{2} \mathrm{O}(80: 20)$ mixture, the two forms (I) and (II) are observed.

${ }^{*}$ From the literature data, it was not possible to assign the resonances of H9, H10 and H11 to a specific form. ${ }^{5}$ As a model of non-conjugated unsaturated fatty acids. 


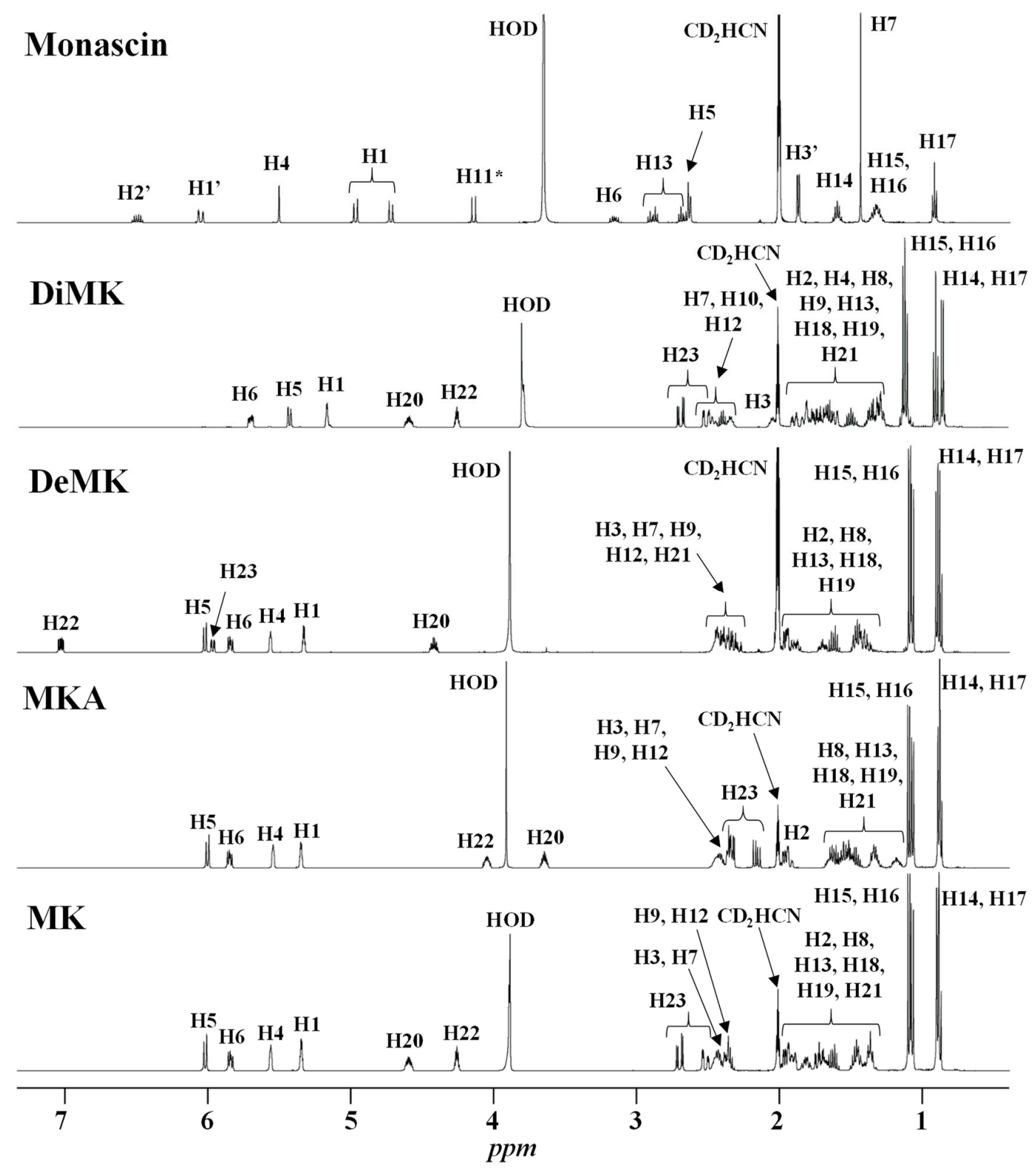

Figure 3. ${ }^{1} \mathrm{H}-\mathrm{NMR}$ spectra of standards of monacolin $\mathrm{K}$ in lactone form (MK) and in hydroxyl acid form (MKA), dehydromonacolin K (DeMK), dihydromonacolin K (DiMK) and monascin recorded in $\mathrm{CD}_{3} \mathrm{CN}: \mathrm{D}_{2} \mathrm{O}(80: 20)$. The chemical structures of all the compounds and their protons numbering are given in Table 2. $\left.{ }^{*}\right)$ The signal of $\mathrm{H} 11$ of monascin disappears with time due to exchange with $\mathrm{D}_{2} \mathrm{O}$.

\subsubsection{Quantitative ${ }^{1} \mathrm{H}-\mathrm{NMR}$ Analysis}

With our experimental conditions, the limit of detection (LOD; for a signal-to-noise ratio $(\mathrm{SNR})=3$ ) of monacolin derivatives in real samples was estimated between $4 \times 10^{-5}$ and $10^{-4} \mathrm{M}$ depending on the multiplicity of the targeted proton signal, corresponding respectively to 0.016 and $0.04 \mathrm{mg}$ of monacolins (considered with the molecular weight of MK $\left.\left(404 \mathrm{~g} \mathrm{~mol}^{-1}\right)\right)$ in the volume of solvent used for the extraction of 20 to $100 \mathrm{mg}$ of RYR formulation. The limit of quantification (LOQ; SNR $=10$ ) for the same signals was evaluated between $10^{-4}$ and $3 \times 10^{-4} \mathrm{M}$, corresponding respectively to 0.04 and $0.12 \mathrm{mg}$ of monacolin derivatives in the amount of powdered RYR extracted. Considering the ratio between the mass of sample extracted and that of the formulation (tablet or powder in the capsule), the LOQ was estimated to be $\approx 0.25 \mathrm{mg}$ of monacolin per capsule or tablet. 
Table 3. ${ }^{1} \mathrm{H}-\mathrm{NMR}$ analysis of RYR dietary supplements: quantitative determination of monacolins (mg per capsule or tablet) ${ }^{1}$ and list of other compounds identified.

\begin{tabular}{|c|c|c|c|c|c|c|c|}
\hline $\begin{array}{c}\text { DS } \\
\text { Number }\end{array}$ & $\begin{array}{l}\text { Signal at } 5.84 \\
\text { ppm }^{2} \mathrm{H} 6\end{array}$ & $\begin{array}{l}\text { Signal at } 5.56 \\
\text { ppm }^{2} \mathrm{H} 4\end{array}$ & $\begin{array}{c}\text { Mean Intensity of } \\
\text { Signals } \\
\text { H6 and H4 }\end{array}$ & $\begin{array}{l}\text { Signal at } 5.33 \\
\text { ppm }^{2} \mathrm{H} 1\end{array}$ & $\begin{array}{l}\text { Signal at } 4.60 \\
\text { ppm }^{2} \mathrm{H} 20\end{array}$ & $\begin{array}{l}\text { Signal at } 4.25 \\
\text { ppm }^{2} \mathrm{H} 22\end{array}$ & $\begin{array}{l}\text { Compounds Identified Other than } \\
\text { Monacolins } 3,4\end{array}$ \\
\hline 1 & 1.67 & 1.70 & 1.685 & 3.31 & 1.40 & 1.34 & SFA *, UFA, glycerol, glucose, monascin \\
\hline 2 & 9.14 & 9.18 & 9.16 & 9.26 & & 7.10 & SFA *, UFA, glycerol, glucose \\
\hline 3 & 3.07 & 3.07 & 3.07 & 2.39 & & & $\begin{array}{c}\text { SFA } * \text { UFA, carnitine }{ }^{*}, \text { vitamin B3 } \\
\text { vitamin } C^{*}\end{array}$ \\
\hline 4 & 1.02 & 0.95 & 0.985 & 1.64 & & 0.71 & SFA, UFA, glucose \\
\hline 5 & 2.47 & 2.53 & 2.50 & 11.3 & 2.15 & & SFA *, UFA, glycerol, glucose, monascin \\
\hline 6 & 2.92 & 2.63 & 2.775 & 3.27 & & 2.19 & SFA *, UFA, glucose, monascin \\
\hline 7 & 3.76 & 3.73 & 3.745 & & & & SFA $*$ UFA, glucose, piperine * \\
\hline 8 & 8.68 & 8.79 & 8.735 & 8.65 & 6.89 & 7.73 & SFA, UFA, glycerol, monascin \\
\hline 9 & 5.14 & 5.21 & 5.125 & 8.03 & 4.55 & 4.55 & SFA *, UFA, glycerol, glucose, monascin \\
\hline 10 & 2.10 & 2.04 & 2.07 & 8.67 & & 1.22 & SFA, UFA, glycerol, glucose, monascin \\
\hline 11 & & & & & & & SFA, UFA, glycerol, glucose, monascin \\
\hline 12 & & & & & & & SFA, UFA, glycerol, glucose, monascin \\
\hline 13 & 23.9 & 23.9 & 23.9 & 21.9 & 23.9 & 23.2 & SFA *, UFA, glycerol, glucose \\
\hline 14 & 3.45 & 3.28 & 3.365 & 10.8 & & 2.26 & SFA, UFA, glycerol, glucose, monascin \\
\hline 15 & 11.9 & 12.3 & 12.1 & & 9.85 & & SFA *, UFA, glycerol, monascin \\
\hline 16 & & 0.31 & & & & & $\begin{array}{c}\text { SFA *, UFA, glycerol, glucose, monascin, } \\
\text { piperine * }\end{array}$ \\
\hline 17 & 1.47 & 1.51 & 1.49 & 4.06 & 1.28 & & SFA, UFA, glycerol, monascin \\
\hline 18 & 8.84 & 8.19 & 8.515 & & 6.68 & 7.04 & SFA *, UFA, glycerol, glucose, monascin \\
\hline 19 & 0.36 & 0.44 & 0.40 & & & & SFA *, UFA, glycerol, glucose, monascin \\
\hline 20 & 1.75 & 1.77 & 1.76 & 3.51 & 1.27 & 1.49 & SFA *, UFA, glycerol, glucose, monascin \\
\hline 21 & 0.48 & 0.47 & 0.475 & & & & SFA *, UFA, glycerol \\
\hline
\end{tabular}


Table 3. Cont

\begin{tabular}{|c|c|c|c|c|c|c|c|}
\hline $\begin{array}{c}\text { DS } \\
\text { Number }\end{array}$ & $\begin{array}{l}\text { Signal at } 5.84 \\
\text { ppm }^{2} \mathrm{H} 6\end{array}$ & $\begin{array}{l}\text { Signal at } 5.56 \\
\text { ppm }^{2} \mathrm{H} 4\end{array}$ & $\begin{array}{c}\text { Mean Intensity of } \\
\text { Signals } \\
\text { H6 and H4 }\end{array}$ & $\begin{array}{l}\text { Signal at } 5.33 \\
\text { ppm }^{2} \mathrm{H} 1\end{array}$ & $\begin{array}{l}\text { Signal at } 4.60 \\
\text { ppm }^{2} \mathrm{H} 20\end{array}$ & $\begin{array}{l}\text { Signal at } 4.25 \\
\text { ppm }^{2} \mathrm{H} 22\end{array}$ & $\begin{array}{l}\text { Compounds Identified Other than } \\
\text { Monacolins } 3,4\end{array}$ \\
\hline 22 & 3.09 & 3.02 & 3.055 & & & 2.26 & SFA *, UFA, glycerol, glucose, monascin \\
\hline 23 & 10.6 & 10.7 & 10.65 & 10.0 & 10.0 & 9.77 & SFA *, UFA, glycerol, glucose, monascin \\
\hline 24 & 11.5 & 11.8 & 11.65 & 9.38 & & 5.97 & SFA *, UFA, glucose, sorbitol * \\
\hline 25 & 10.0 & 9.72 & 9.87 & & 5.97 & 7.26 & SFA, UFA, glycerol, monascin \\
\hline 26 & 4.51 & 4.54 & 4.525 & & & 3.88 & SFA *, UFA, glycerol, glucose, sorbitol \\
\hline 27 & 4.13 & 3.84 & 3.985 & & 2.97 & 2.90 & $\begin{array}{l}\text { SFA, UFA, glycerol, glucose, monascin, } \\
\text { chlorogenic acid * }\end{array}$ \\
\hline 28 & 1.64 & 1.75 & 1.695 & & 1.05 & 1.31 & SFA *, UFA, glycerol, glucose \\
\hline 29 & & & & & & & SFA *, UFA, glycerol, glucose \\
\hline 30 & 2.99 & 3.04 & 3.015 & 2.61 & & 2.43 & SFA, UFA \\
\hline 31 & 1.21 & 1.28 & 1.245 & 2.16 & & & $\begin{array}{l}\text { SFA *, UFA, glycerol, glucose, monascin, } \\
\text { isopropanol }\end{array}$ \\
\hline
\end{tabular}


The $\mathrm{H} 5$ resonance (6.01 ppm) was not used for the quantification of monacolins as it may also contain part of the signal (ddd) of the H23 of DeMK at $5.97 \mathrm{ppm}$ and can be slightly overlapped with the H1' signal (qd) of monascin at $6.05 \mathrm{ppm}$. The H6 (5.84 ppm) and H4 (5.56 ppm) resonances are not hindered by signals of other molecules and they have been quantified respectively in 27 and 28 RYR DS as no monacolin signal was detected in formulations 11, 12 and 29 whereas both resonances were observed in DS $\mathbf{1 6}$ where only the H4 signal could be quantified with an intensity at the LOQ level. The amount of monacolins in lactone form was determined from either $\mathrm{H} 20$ or $\mathrm{H} 22$ or both signals in only 22 RYR DS because of significant overlap with matrix signals in some formulations. It was possible to quantify the $\mathrm{H} 1$ signal (5.33 ppm) in only 17 formulations due to its overlap with the large resonance of the ethylenic protons of non-conjugated UFA at $\approx 5.36 \mathrm{ppm}$ and maybe also of other compounds. The $2 \mathrm{D}^{1} \mathrm{H}_{-}{ }^{13} \mathrm{C}$ HSQC-NMR experiment recorded for the DS 15 and illustrated in Figure 4 clearly shows these findings.

The intensity of the DeMK ddd resonance (H22 at $7.03 \mathrm{ppm}$ ) was low or very low and overlapped with matrix signals in most sample spectra and could not thus be quantified precisely. The dd resonance of DiMK at 5.69 ppm was not clearly detected in any formulation and could not thus be quantified. The signal intensities of monacolins in hydroxyl acid form (H22 at 4.05 ppm and H20 at 3.63 ppm) would have allowed their quantification in most of the formulations but their substantial overlap with the resonances of matrix compounds did not permit to obtain accurate values without curve deconvolution treatment.

The monacolin contents determined by ${ }^{1} \mathrm{H}-\mathrm{NMR}$ are reported in Table 3. For more clarity, the coefficient of variation (CV) and the relative standard deviations (RSD) are given in Table S2. The RSD of the ${ }^{1} \mathrm{H}-\mathrm{NMR}$ assays ranged between $1.5 \%$ and $13 \%$. The relevance of the ${ }^{1} \mathrm{H}-\mathrm{NMR}$ data will be discussed later when compared to those obtained by UHPLC.

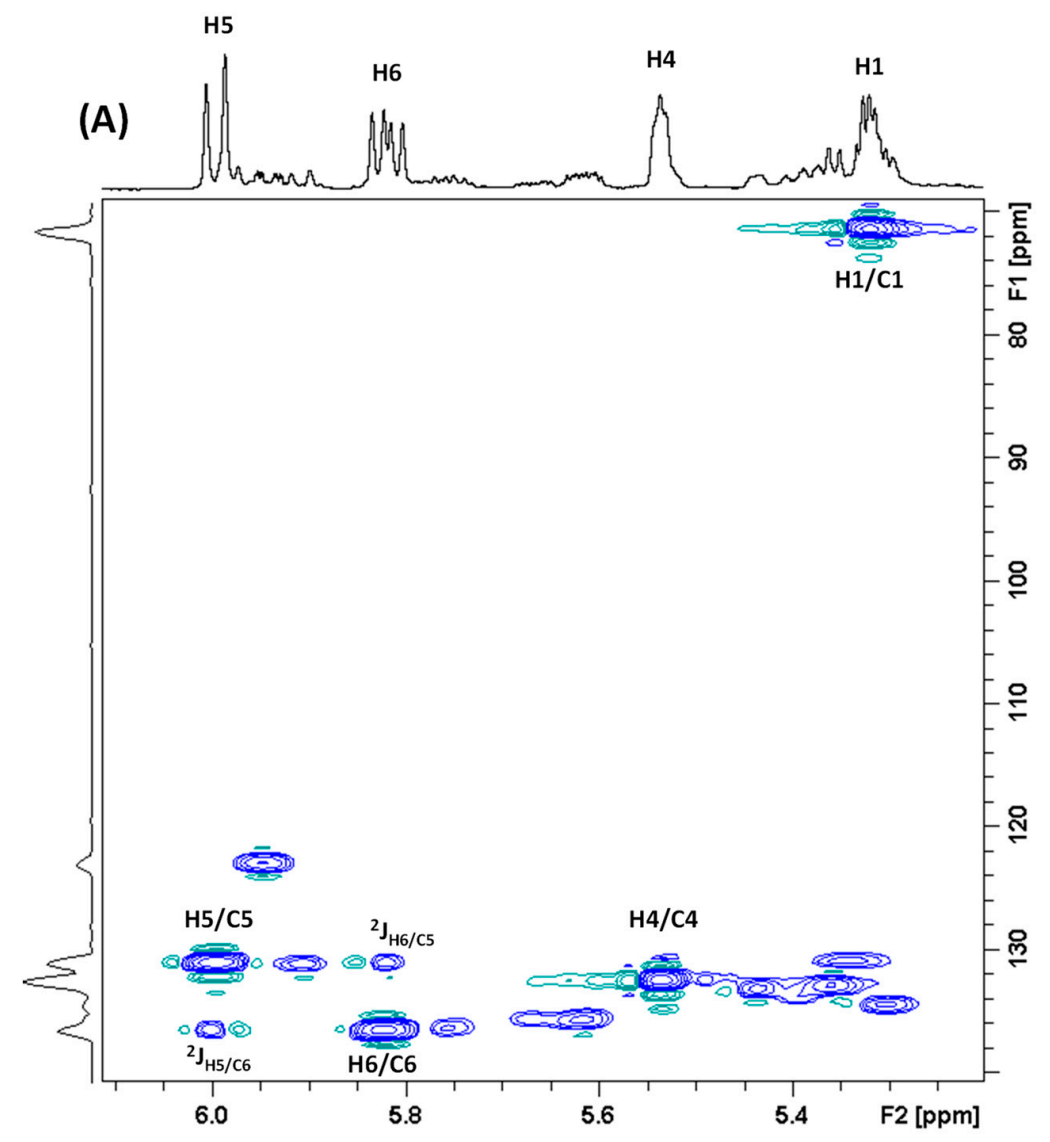

Figure 4. Cont. 


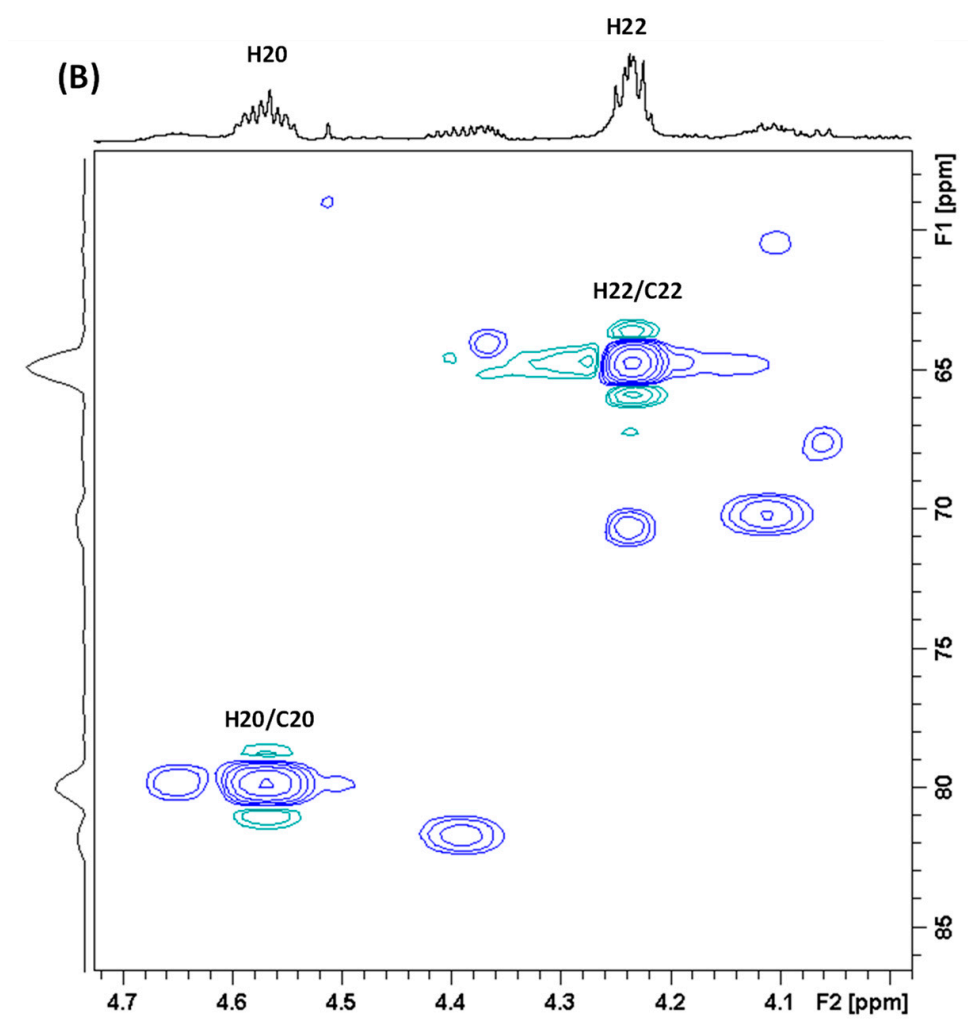

Figure 4. $2 \mathrm{D}^{1} \mathrm{H}_{-}{ }^{13} \mathrm{C}$ HSQC-NMR spectrum of the dietary supplement 15 recorded in $\mathrm{CD}_{3} \mathrm{CN}: \mathrm{D}_{2} \mathrm{O}$ (80:20). (A) ${ }^{1} \mathrm{H}$ enlarged region 5.2-6.1 ppm. (B) ${ }^{1} \mathrm{H}$ enlarged region 3.98-4.72 ppm. The proton numbering of monacolins is given in Table 2 .

\subsection{Chromatographic Analysis}

\subsubsection{Identification of Monacolins and Pigments}

RYR formulations were traced by UHPLC-DAD-MS. Among the great number of compounds observed, 23 (12 monacolins and 11 azaphilones; see Figure 2 for their chemical structures) were identified by comparing with the literature their elution sequence, their UV-Vis and MS profiles as well as the accurate mass measurements of their parent and fragment ions in High Resolution Electrospray Ionization (HR-ESI) MS and MS/MS [13,26]. Moreover, the identification of MK, CP, MKA, DeMK, DiMK, citrinin and monascin was confirmed by comparing their UV-Vis and MS and MS/MS chromatographic profiles with those of the corresponding standards. The retention time (tR), UV-Vis $\lambda_{\max }$, accurate masses of parent ion and of its MS/MS major fragment ions for each compound identified are gathered in Table 4. We will not describe the process that allowed the identification of the 23 compounds but we will show the respective contributions of UV-Vis and HR-MS and MS/MS to determine their chemical structure through some selected examples.

The UV-Vis absorption spectra gave some indication on the chemical structure of the compounds detected. For example, all the monacolins with a conjugated hexahydronaphthalene ring displayed the same characteristic mountain-like UV spectrum with three maximum absorptions at $\approx 230$, 238 and $246 \mathrm{~nm}$ (range 229-230, 238-239 and 244-247 nm) (Table 4) in accordance with literature data $[1,10,27,28])$. Due to the absence of conjugated double bonds, the dihydromonacolins with an octahydronaphthalene ring and so an UV maximum absorption band at $\approx 210 \mathrm{~nm}[1,20]$ were not detected at the wavelength used in this study $(238 \mathrm{~nm})$. In the same way, the yellow azaphilone pigments with the classical monascin-type chromophore showed specific profiles with high intensity peaks at 227-233 and 386-392 nm and a very low intensity band at $285-291 \mathrm{~nm}$, while the red ones with the rubropunctamine-type chromophore presented specific absorbances at 251-252, 302-307, 412-423 and 525-530 $\mathrm{nm}$ (Table 4), all these values being in agreement with literature reports [29-34]. 
Table 4. Retention times, UV-Vis characteristics and accurate mass measurements of the compounds observed and identified from the RYR dietary supplements analyzed with UHPLC.

\begin{tabular}{|c|c|c|c|c|c|c|c|c|c|}
\hline Compound Name & $\begin{array}{l}\text { Retention } \\
\text { Time } \\
\text { (min) }\end{array}$ & $\begin{array}{l}\text { UV-Vis } \lambda_{\max } \\
\quad(\mathrm{nm})\end{array}$ & $\begin{array}{c}\text { Formula } \\
\text { (Monoisotopic } \\
\text { Mass) }\end{array}$ & \multicolumn{2}{|c|}{$\begin{array}{l}\text { Calculated Mass } \\
\qquad(\mathrm{m} / \mathrm{z})\end{array}$} & $\begin{array}{l}\text { Measured } \\
\text { Mass } \\
(\mathrm{m} / \mathrm{z})\end{array}$ & $\begin{array}{c}\text { Mass } \\
\text { Error } \\
(\mathrm{mDa})\end{array}$ & $\begin{array}{l}\text { Relative } \\
\text { Mass Error } \\
\text { (ppm) }\end{array}$ & $\begin{array}{c}\text { Major ions of }[\mathrm{M}+\mathrm{H}]^{+} \mathrm{MS} / \mathrm{MS} \\
\text { Fragmentation Unless } \\
\text { Otherwise Indicated }(\mathrm{m} / \mathrm{z})\end{array}$ \\
\hline $\begin{array}{l}\text { Monacolin J hydroxyl } \\
\text { acid (MJA) }\end{array}$ & 0.90 & $230,239,244$ & $\begin{array}{l}\mathrm{C}_{19} \mathrm{H}_{30} \mathrm{O}_{5} \\
(338.2172)\end{array}$ & {$[\mathrm{M}-\mathrm{H}]^{-}$} & 337.2015 & 337.2010 & -0.5 & -1.5 & Not recorded \\
\hline Citrinin & 1.45 & $243,326^{1}$ & $\begin{array}{l}\mathrm{C}_{13} \mathrm{H}_{14} \mathrm{O}_{5} \\
(250.0841)\end{array}$ & {$[\mathrm{M}+\mathrm{H}]^{+}$} & 251.0919 & 251.0922 & +0.3 & +1.2 & Not recorded \\
\hline Monacolin J (MJ) & 1.98 & $230,239,246$ & $\begin{array}{l}\mathrm{C}_{19} \mathrm{H}_{28} \mathrm{O}_{4} \\
(320.1988)\end{array}$ & $\begin{array}{l}{[\mathrm{M}+\mathrm{H}]^{+}} \\
{[\mathrm{M}+\mathrm{Na}]^{+}} \\
{[\mathrm{M}-\mathrm{H}]^{-}}\end{array}$ & $\begin{array}{l}321.2066 \\
343.1885 \\
319.1909\end{array}$ & $\begin{array}{l}321.2067 \\
343.1881 \\
319.1910\end{array}$ & $\begin{array}{l}+0.1 \\
-0.4 \\
+0.1\end{array}$ & $\begin{array}{l}+0.3 \\
-1.2 \\
+0.3\end{array}$ & $\begin{array}{l}\text { 303.1945, 285.1847, 267.1711, } \\
\text { 205.1604, 199.1451, 159.1162 }\end{array}$ \\
\hline Rubropunctamine & 2.70 & $\begin{array}{l}252,303,415 \\
525\end{array}$ & $\begin{array}{l}\mathrm{C}_{21} \mathrm{H}_{23} \mathrm{NO}_{4} \\
(353.1627)\end{array}$ & $\begin{array}{c}{[\mathrm{M}+\mathrm{H}]^{+}} \\
{[\mathrm{M}+\mathrm{Na}]^{+}} \\
{[\mathrm{M}-\mathrm{H}]^{-}}\end{array}$ & $\begin{array}{l}354.1705 \\
376.1525 \\
352.1549\end{array}$ & $\begin{array}{l}354.1710 \\
376.1521 \\
352.1551\end{array}$ & $\begin{array}{l}+0.5 \\
-0.4 \\
+0.2\end{array}$ & $\begin{array}{l}+1.4 \\
-1.1 \\
+0.6\end{array}$ & $\begin{array}{c}337.1308,294.0762,267.0523 \\
256.0866,239.0580\end{array}$ \\
\hline Monacolin N (MN) & 3.89 & $230,239,247$ & $\begin{array}{l}\mathrm{C}_{21} \mathrm{H}_{30} \mathrm{O}_{5} \\
(362.2093)\end{array}$ & $\begin{array}{c}{[\mathrm{M}+\mathrm{H}]^{+}} \\
{[\mathrm{M}+\mathrm{Na}]^{+}}\end{array}$ & $\begin{array}{l}363.2171 \\
385.1991\end{array}$ & $\begin{array}{l}363.2159 \\
385.1988\end{array}$ & $\begin{array}{l}-1.2 \\
-0.3\end{array}$ & $\begin{array}{l}-3.3 \\
-0.8\end{array}$ & $\begin{array}{c}\text { 345.2052, 285.1865, 267.1750 } \\
243.1711,199.1490,173.1335 \\
159.1173,143.0856\end{array}$ \\
\hline $\begin{array}{c}\text { Monacolin L } \\
\text { hydroxyl acid (MLA) }\end{array}$ & 4.05 & $230,239,247$ & $\begin{array}{l}\mathrm{C}_{19} \mathrm{H}_{30} \mathrm{O}_{4} \\
(322.2144)\end{array}$ & $\begin{array}{c}{[\mathrm{M}+\mathrm{H}]^{+}} \\
{[\mathrm{M}+\mathrm{Na}]^{+}} \\
{[\mathrm{M}-\mathrm{H}]^{-}}\end{array}$ & $\begin{array}{l}323.2222 \\
345.2042 \\
321.2066\end{array}$ & $\begin{array}{l}323.2220 \\
345.2037 \\
321.2072\end{array}$ & $\begin{array}{l}-0.2 \\
-0.5 \\
+0.6\end{array}$ & $\begin{array}{l}-0.6 \\
-1.5 \\
+1.9\end{array}$ & $\begin{array}{l}305.2126,287.1986,269.1901 \\
225.1640,203.1800,159.1172\end{array}$ \\
\hline Monacolin X (MX) & 4.38 & $230,239,246$ & $\begin{array}{l}\mathrm{C}_{24} \mathrm{H}_{34} \mathrm{O}_{6} \\
(418.2355)\end{array}$ & $\begin{array}{c}{[\mathrm{M}+\mathrm{H}]^{+}} \\
{[\mathrm{M}+\mathrm{Na}]^{+}}\end{array}$ & $\begin{array}{l}419.2434 \\
441.2253\end{array}$ & $\begin{array}{l}419.2434 \\
441.2250\end{array}$ & $\begin{array}{c}0 \\
-0.3\end{array}$ & $\begin{array}{c}0 \\
-0.7\end{array}$ & $\begin{array}{l}303.1961,285.1855,267.1749, \\
243.1751,225.1643,199.1489 \\
173.1331,159.1173,143.0712\end{array}$ \\
\hline $\begin{array}{l}\text { 7-(2-hydroxyethyl)- } \\
\text { monascorubramine } \\
\text { (PP-R) }\end{array}$ & 4.66 & $\begin{array}{c}251,302,423 \\
530\end{array}$ & $\begin{array}{l}\mathrm{C}_{25} \mathrm{H}_{31} \mathrm{NO}_{5} \\
(425.2202)\end{array}$ & $\begin{array}{c}{[\mathrm{M}+\mathrm{H}]^{+}} \\
{[\mathrm{M}+\mathrm{Na}]^{+}}\end{array}$ & $\begin{array}{l}426.2280 \\
448.2100\end{array}$ & $\begin{array}{l}426.2265 \\
448.2092\end{array}$ & $\begin{array}{l}-1.5 \\
-0.8\end{array}$ & $\begin{array}{l}-3.5 \\
-1.8\end{array}$ & Not recorded \\
\hline Monascorubramine & 5.55 & $\begin{array}{c}251,307,412 \\
530\end{array}$ & $\begin{array}{l}\mathrm{C}_{23} \mathrm{H}_{27} \mathrm{NO}_{4} \\
(381.1940)\end{array}$ & $\begin{array}{l}{[\mathrm{M}+\mathrm{H}]^{+}} \\
{[\mathrm{M}+\mathrm{Na}]^{+}} \\
{[\mathrm{M}-\mathrm{H}]^{-}}\end{array}$ & $\begin{array}{l}382.2018 \\
404.1838 \\
380.1862\end{array}$ & $\begin{array}{l}382.2018 \\
404.1842 \\
380.1867\end{array}$ & $\begin{array}{c}0 \\
+0.4 \\
+0.5\end{array}$ & $\begin{array}{c}0 \\
+1.0 \\
+1.3\end{array}$ & $\begin{array}{c}\text { 365.1624, 294.0765, 267.0528 } \\
250.0870,239.0582\end{array}$ \\
\hline $\begin{array}{c}\text { Monacolin K } \\
\text { hydroxyl acid (MKA) }\end{array}$ & 5.64 & $229,238,246$ & $\begin{array}{l}\mathrm{C}_{24} \mathrm{H}_{38} \mathrm{O}_{6} \\
(422.2669)\end{array}$ & $\begin{array}{c}{[\mathrm{M}+\mathrm{H}]^{+}} \\
{[\mathrm{M}+\mathrm{Na}]^{+}} \\
{[\mathrm{M}-\mathrm{H}]^{-}} \\
{[\mathrm{M}-\mathrm{H}+} \\
\mathrm{CO}]^{-}\end{array}$ & $\begin{array}{l}423.2747 \\
445.2566 \\
421.2590 \\
449.2539\end{array}$ & $\begin{array}{c}\mathrm{ND}^{2} \\
445.2561 \\
421.2589 \\
449.2540\end{array}$ & $\begin{array}{l}-0.5 \\
-0.1 \\
+0.1\end{array}$ & $\begin{array}{l}-1.1 \\
-0.2 \\
+0.2\end{array}$ & $\begin{array}{c}\text { MS/MS [M - H] }]^{-} 319.1902 \\
101.0602,85.0286\end{array}$ \\
\hline $\begin{array}{c}\text { Monascuspiloin } \\
\text { (dihydromonascin) }\end{array}$ & 5.92 & $233,291,390$ & $\begin{array}{l}\mathrm{C}_{21} \mathrm{H}_{28} \mathrm{O}_{5} \\
(360.1937)\end{array}$ & $\begin{array}{c}{[\mathrm{M}+\mathrm{H}]^{+}} \\
{[\mathrm{M}+\mathrm{Na}]^{+}}\end{array}$ & $\begin{array}{l}361.2015 \\
383.1834\end{array}$ & $\begin{array}{l}361.2009 \\
383.1836\end{array}$ & $\begin{array}{l}-0.6 \\
+0.2\end{array}$ & $\begin{array}{l}-1.7 \\
+0.5\end{array}$ & $\begin{array}{c}345.2045,300.2883,261.1133 \\
215.1081,187.1134\end{array}$ \\
\hline
\end{tabular}


Table 4. Cont

\begin{tabular}{|c|c|c|c|c|c|c|c|c|c|}
\hline Compound Name & $\begin{array}{l}\text { Retention } \\
\text { Time } \\
\text { (min) }\end{array}$ & $\begin{array}{l}\text { UV-Vis } \lambda_{\max } \\
\quad(\mathrm{nm})\end{array}$ & $\begin{array}{c}\text { Formula } \\
\text { (Monoisotopic } \\
\text { Mass) }\end{array}$ & \multicolumn{2}{|c|}{$\begin{array}{l}\text { Calculated Mass } \\
\qquad(\mathrm{m} / \mathrm{z})\end{array}$} & $\begin{array}{l}\text { Measured } \\
\text { Mass } \\
(\mathrm{m} / \mathrm{z})\end{array}$ & $\begin{array}{l}\text { Mass } \\
\text { Error } \\
(\mathrm{mDa})\end{array}$ & $\begin{array}{l}\text { Relative } \\
\text { Mass Error } \\
(\mathrm{ppm})\end{array}$ & $\begin{array}{c}\text { Major ions of }[\mathrm{M}+\mathrm{H}]^{+} \mathrm{MS} / \mathrm{MS} \\
\text { Fragmentation Unless } \\
\text { Otherwise Indicated }(\mathrm{m} / \mathrm{z})\end{array}$ \\
\hline Monacolin L (ML) & 6.09 & $230,238,246$ & $\begin{array}{l}\mathrm{C}_{19} \mathrm{H}_{28} \mathrm{O}_{3} \\
(304.2039)\end{array}$ & $\begin{array}{l}{[\mathrm{M}+\mathrm{H}]^{+}} \\
{[\mathrm{M}+\mathrm{Na}]^{+}}\end{array}$ & $\begin{array}{l}305.2117 \\
327.1936\end{array}$ & $\begin{array}{l}305.2116 \\
327.1935\end{array}$ & $\begin{array}{l}-0.1 \\
-0.1\end{array}$ & $\begin{array}{l}-0.3 \\
-0.3\end{array}$ & $\begin{array}{c}287.2004,269.1902,251.1179 \\
225.1649,203.1797,201.1643 \\
199.1488,173.1333,159.1174 \\
145.1015\end{array}$ \\
\hline $\begin{array}{l}\text { Compactin }(\mathrm{CP}) \\
\text { (mevastatin) }\end{array}$ & 6.18 & $230,238,246$ & $\begin{array}{l}\mathrm{C}_{23} \mathrm{H}_{34} \mathrm{O}_{5} \\
(390.2406)\end{array}$ & $\begin{array}{c}{[\mathrm{M}+\mathrm{H}]^{+}} \\
{[\mathrm{M}+\mathrm{Na}]^{+}}\end{array}$ & $\begin{array}{l}391.2484 \\
413.2304\end{array}$ & $\begin{array}{l}391.2488 \\
413.2305\end{array}$ & $\begin{array}{l}+0.4 \\
+0.1\end{array}$ & $\begin{array}{l}+1.0 \\
+0.2\end{array}$ & $\begin{array}{c}\text { 289.1793, } 271.1693,253.1588 \\
229.1587,211.1481,185.1324 \\
159.1168\end{array}$ \\
\hline Monasfluore A & 6.28 & $379^{3}$ & $\begin{array}{l}\mathrm{C}_{21} \mathrm{H}_{24} \mathrm{O}_{5} \\
(356.1624)\end{array}$ & $\begin{array}{l}{[\mathrm{M}+\mathrm{H}]^{+}} \\
{[\mathrm{M}+\mathrm{Na}]^{+}}\end{array}$ & $\begin{array}{l}357.1702 \\
379.1521\end{array}$ & $\begin{array}{l}357.1701 \\
379.1522\end{array}$ & $\begin{array}{l}-0.1 \\
+0.1\end{array}$ & $\begin{array}{l}-0.3 \\
+0.3\end{array}$ & Not recorded \\
\hline Monaphilone B & 7.23 & $227,285,386$ & $\begin{array}{l}\mathrm{C}_{20} \mathrm{H}_{28} \mathrm{O}_{4} \\
(332.1988)\end{array}$ & $\begin{array}{l}{[\mathrm{M}+\mathrm{H}]^{+}} \\
{[\mathrm{M}+\mathrm{Na}]^{+}}\end{array}$ & $\begin{array}{l}333.2066 \\
355.1885\end{array}$ & $\begin{array}{l}333.2062 \\
355.1880\end{array}$ & $\begin{array}{l}-0.4 \\
-0.5\end{array}$ & $\begin{array}{l}-1.2 \\
-1.4\end{array}$ & $\begin{array}{c}\text { 287.2012, 217.1234, 201.0911 } \\
189.1385,173.0970\end{array}$ \\
\hline $\begin{array}{l}\text { Monacolin K (MK) } \\
\text { (lovastatin) }\end{array}$ & 7.79 & $229,238,246$ & $\begin{array}{l}\mathrm{C}_{24} \mathrm{H}_{36} \mathrm{O}_{5} \\
(404.2563)\end{array}$ & $\begin{array}{c}{[\mathrm{M}+\mathrm{H}]^{+}} \\
{[\mathrm{M}+\mathrm{Na}]^{+}} \\
{[2 \mathrm{M}+} \\
\mathrm{Na}]^{+}\end{array}$ & $\begin{array}{l}405.2641 \\
427.2460 \\
831.5023\end{array}$ & $\begin{array}{l}405.2642 \\
427.2461 \\
831.5026\end{array}$ & $\begin{array}{l}+0.1 \\
+0.1 \\
+0.3\end{array}$ & $\begin{array}{l}+0.3 \\
+0.3 \\
+0.4\end{array}$ & $\begin{array}{l}\text { 303.1995, 285.1855, 267.1753, } \\
\text { 243.1751, 225.1652, 199.1490, } \\
173.1328,159.1176,143.0854\end{array}$ \\
\hline Monascin & 8.19 & $232,291,392$ & $\begin{array}{l}\mathrm{C}_{21} \mathrm{H}_{26} \mathrm{O}_{5} \\
(358.1781)\end{array}$ & $\begin{array}{l}{[\mathrm{M}+\mathrm{H}]^{+}} \\
{[\mathrm{M}+\mathrm{Na}]^{+}}\end{array}$ & $\begin{array}{l}359.1859 \\
381.1678\end{array}$ & $\begin{array}{l}359.1854 \\
381.1684\end{array}$ & $\begin{array}{l}-0.5 \\
+0.6\end{array}$ & $\begin{array}{l}-1.4 \\
+1.6\end{array}$ & $\begin{array}{c}\text { 343.2274, 315.2317, } 261.1112 \\
215.1073,187.1121\end{array}$ \\
\hline $\begin{array}{l}\text { Dihydromonacolin K } \\
\text { (DiMK) }\end{array}$ & 9.78 & $\mathrm{ND}^{4}$ & $\begin{array}{l}\mathrm{C}_{24} \mathrm{H}_{38} \mathrm{O}_{5} \\
(406.2719)\end{array}$ & $\begin{array}{l}{[\mathrm{M}+\mathrm{H}]^{+}} \\
{[\mathrm{M}+\mathrm{Na}]^{+}}\end{array}$ & $\begin{array}{l}407.2798 \\
429.2617\end{array}$ & $\begin{array}{l}407.2796 \\
429.2618\end{array}$ & $\begin{array}{l}-0.2 \\
+0.1\end{array}$ & $\begin{array}{l}-0.5 \\
+0.2\end{array}$ & $\begin{array}{c}\text { 305.2115, 287.2015, 269.1899 } \\
227.1797,203.1802\end{array}$ \\
\hline Monasfluore B & 9.97 & $378^{3}$ & $\begin{array}{l}\mathrm{C}_{23} \mathrm{H}_{28} \mathrm{O}_{5} \\
(384.1937)\end{array}$ & $\begin{array}{c}{[\mathrm{M}+\mathrm{H}]^{+}} \\
{[\mathrm{M}+\mathrm{Na}]^{+}}\end{array}$ & $\begin{array}{l}385.2015 \\
407.1835\end{array}$ & $\begin{array}{c}\mathrm{ND}^{2} \\
407.1839\end{array}$ & +0.4 & +1.0 & Not recorded \\
\hline $\begin{array}{l}\text { Dehydromonacolin L } \\
\text { (DeML) }\end{array}$ & 10.15 & $230,238,246$ & $\begin{array}{l}\mathrm{C}_{19} \mathrm{H}_{26} \mathrm{O}_{2} \\
(286.1933)\end{array}$ & $\begin{array}{c}{[\mathrm{M}+\mathrm{H}]^{+}} \\
{[\mathrm{M}+\mathrm{Na}]^{+}}\end{array}$ & $\begin{array}{l}287.2011 \\
309.1830\end{array}$ & $\begin{array}{l}287.2007 \\
\mathrm{ND}^{2}\end{array}$ & -0.4 & -1.4 & $\begin{array}{c}\text { 269.1896, 225.1636, 201.1645, } \\
\text { 199.1483, 173.1329, 159.1171, } \\
145.1013\end{array}$ \\
\hline Monaphilone A & 11.15 & $230,289,389$ & $\begin{array}{l}\mathrm{C}_{22} \mathrm{H}_{32} \mathrm{O}_{4} \\
(360.2301)\end{array}$ & $\begin{array}{l}{[\mathrm{M}+\mathrm{H}]^{+}} \\
{[\mathrm{M}+\mathrm{Na}]^{+}}\end{array}$ & $\begin{array}{l}361.2379 \\
383.2198\end{array}$ & $\begin{array}{c}361.2380 \\
\mathrm{ND}^{2}\end{array}$ & +0.1 & +0.3 & $\begin{array}{c}\text { 287.2020, } 217.1322,189.1390 \\
173.0952\end{array}$ \\
\hline $\begin{array}{l}\text { Dehydromonacolin K } \\
\text { (DeMK) }\end{array}$ & 11.42 & $230,238,246$ & $\begin{array}{l}\mathrm{C}_{24} \mathrm{H}_{34} \mathrm{O}_{4} \\
(386.2457)\end{array}$ & $\begin{array}{c}{[\mathrm{M}+\mathrm{H}]^{+}} \\
{[\mathrm{M}+\mathrm{Na}]^{+}} \\
{[2 \mathrm{M}+} \\
\mathrm{Na}]^{+}\end{array}$ & $\begin{array}{l}387.2535 \\
409.2355 \\
795.4812\end{array}$ & $\begin{array}{l}387.2532 \\
409.2356 \\
795.4821\end{array}$ & $\begin{array}{l}-0.3 \\
+0.1 \\
+0.9\end{array}$ & $\begin{array}{l}-0.8 \\
+0.3 \\
+1.1\end{array}$ & $\begin{array}{c}\text { 345.2037, 285.1851, 267.1747, } \\
\text { 249.1625, 199.1484, 173.1325, } \\
159.1167,143.0858\end{array}$ \\
\hline Ankaflavin & 11.75 & $232,290,391$ & $\begin{array}{l}\mathrm{C}_{23} \mathrm{H}_{30} \mathrm{O}_{5} \\
(386.2093)\end{array}$ & $\begin{array}{c}{[\mathrm{M}+\mathrm{H}]^{+}} \\
{[\mathrm{M}+\mathrm{Na}]^{+}}\end{array}$ & $\begin{array}{l}387.2172 \\
409.1991\end{array}$ & $\begin{array}{l}387.2173 \\
409.1994\end{array}$ & $\begin{array}{l}+0.1 \\
+0.3\end{array}$ & $\begin{array}{l}+0.3 \\
+0.7\end{array}$ & $\begin{array}{c}359.2238,315.2325,261.1117 \\
215.1076,187.1125\end{array}$ \\
\hline
\end{tabular}

${ }^{1}$ The UV absorption bands at 243 and $326 \mathrm{~nm}$ (low broad) match well with the UV profile reported in the literature for UHPLC-DAD analytical conditions similar to those used in our study $\left(\lambda_{\max }\right.$ at 240, 282 (shoulder) and 333 (low broad) nm) [35]. ${ }^{2}$ ND: not detected. ${ }^{3}$ This low and broad UV absorption band is in agreement with the mean of the $\lambda_{\max }$ of the two enlarged and poorly separated peaks at 371 and $386 \mathrm{~nm}$ reported in the literature [36]. ${ }^{4} \mathrm{ND}$ : not detected at the wavelength used in this study (238 nm). 
Nevertheless, the unambiguous determination of compound identity required the additional use of HR-MS and HR-MS/MS. For instance, the UV absorption spectrum of the compound eluting at $t R$ 3.89 min with $\lambda_{\max }$ at 230, 239 and $247 \mathrm{~nm}$ was characteristic of monacolins. Its protonated molecular ion $[\mathrm{M}+\mathrm{H}]^{+}$at $m / z 363.2159$ and sodium adduct ion $[\mathrm{M}+\mathrm{Na}]^{+}$at $m / z 385.1988$ were in agreement with respectively the calculated masses 363.2171 of $\mathrm{C}_{21} \mathrm{H}_{31} \mathrm{O}_{5}$ (relative mass error (RME) - 3.3 ppm) and 385.1991 of $\mathrm{C}_{21} \mathrm{H}_{30} \mathrm{O}_{5} \mathrm{Na}$ (RME - $0.8 \mathrm{ppm}$ ) suggesting a $\mathrm{C}_{21} \mathrm{H}_{30} \mathrm{O}_{5}$ molecular formula (Table 4). Moreover, the MS/MS product ions obtained were characteristic of the fragmentation pathway of monacolins (Table 4) $[13,14,26]$. So, the compound detected was a monacolin derivative that might be monacolin $\mathrm{N}$ (MN) or dehydromonacolin $\mathrm{N}$ hydroxyl acid (DeMNA) recently described by Li et al. [26]. We propose that it was $\mathrm{MN}$ based on the fact that its $\mathrm{tR}$ at $-0.16 \mathrm{~min}$ with respect to monacolin $\mathrm{L}$ in hydroxyl acid form (MLA) was in agreement with the value given by Li et al. for MN (-0.22 min) and not for DeMNA (+1.72 min). Moreover, DeMNA was detected only at trace level using nanoflow HPLC-Chip-MS whereas MN was also detected by conventional HPLC-MS which is much less sensitive [26].

The identification of the compound eluting at $9.78 \mathrm{~min}$ is another example of the interest of coupling tR, UV-Vis profile and HR-MS spectra. This compound was not detected at $238 \mathrm{~nm}$ but only by its UHPLC-MS profile exhibiting a molecular ion $[\mathrm{M}+\mathrm{H}]^{+}$at $m / z$ 407. Among the known monacolins, two have a nominal mass of 406: DiMK $\left(\mathrm{C}_{24} \mathrm{H}_{38} \mathrm{O}_{5}\right)$ with an exact mass for $[\mathrm{M}+\mathrm{H}]^{+}$at $m / z 407.2798$ and monacolin $\mathrm{M}\left(\mathrm{MM} ; \mathrm{C}_{23} \mathrm{H}_{34} \mathrm{O}_{6}\right)$ with an exact mass for $[\mathrm{M}+\mathrm{H}]^{+}$at $m / z$ 407.2434. The measured mass of the $[\mathrm{M}+\mathrm{H}]^{+}$ion at $m / z 407.2796$ indicated that the compound was DiMK. Furthermore, its MS/MS fragmentation pattern gave the same ions than MK but with 2 more $m / z$ units $(305,287,269 \ldots$ compared to $303,285,267 \ldots$ ) confirming that a double bond of the fused ring was hydrogenated (Table 4), whereas MS/MS fragmentation behavior of MM is identical to that of MK [26]. Also, MM eluted between MJ and MLA with a relative $t R$ versus MJ of 1.2-1.3 [13,26] and hence, in our UHPLC conditions, MM would be expected at 2.4-2.6 min and not at $9.78 \mathrm{~min}$. The incorrect assignment of this compound to MM by Li et al. in 2004 [10] was based on the mountain-like UV spectrum centred at 238 $n m$ characteristic of classical monacolins and on the MS $[\mathrm{M}+\mathrm{H}]^{+}$ion at $m / z 407$, but the UV absorption and the $[\mathrm{M}+\mathrm{H}]^{+}$peak did not correspond to the same compound. Indeed, the compound with an UV absorbance at $238 \mathrm{~nm}$ was very probably dehydromonacolin L (DeML), a monacolin analogue described for the first time in 2011 [37] whose tR is close to that of DiMK (Table 4) [26].

Monacolins and pigments identified in each RYR formulation are listed in Table 5. UHPLC UV-Vis and MS profiles of five characteristic RYR DS, one with only monacolins (formulation 13), two with mainly monacolins (formulations 10 and 30) and two with more pigments than monacolins (formulations 12 and 16) are illustrated in Figure 5 (the UHPLC UV-Vis and MS profiles of nine other RYR DS analyzed are shown in Figure S2). MK was detected in all the samples analyzed and MKA and DeMK in respectively 28 and 29 DS. MLA, ML, CP, DiMK and DeML were found in 18-22 DS, MJ in 11 and $\mathrm{MN}$ in 8 . The other monacolins were observed only in few samples: one for monacolin J in hydroxyl acid form (MJA) and two for monacolin X (MX). MM cannot be found in any RYR DS. The mycotoxin citrinin was only detected at trace level in two samples. Among the yellow azaphilone pigments, monascin, monascuspiloin and monaphilone B were identified respectively in 18, 15 and 21 of the RYR DS analyzed, whereas ankaflavin, monaphilone A, monasfluore A and B were found in few samples $(6,4,5$ and 3 respectively). The red azaphilone pigments, rubropunctamine, monascorubramine and PP-R, were identified in 11, 4 and 2 samples, respectively.

\subsubsection{Quantitative Analysis of Monacolins}

The LOD and LOQ of standard lovastatin, established for SNR 3 and 10, were respectively $0.4 \times 10^{-3} \mathrm{mg} \mathrm{mL}^{-1}$ and $1.5 \times 10^{-3} \mathrm{mg} \mathrm{mL}^{-1}$ corresponding to $0.4 \mu \mathrm{g}$ and $1.5 \mu \mathrm{g}$ in the 10 to $100 \mathrm{mg}$ of powdered. 
Table 5. Chemical fingerprints of the RYR dietary supplements analyzed by UHPLC and quantitative determination of the monacolins identified (mg per capsule or tablet).

\begin{tabular}{|c|c|c|c|c|c|c|c|c|c|c|c|c|c|c|c|c|c|}
\hline \multirow[t]{2}{*}{ DS } & \multicolumn{12}{|c|}{ Monacolins $^{1}$} & \multirow{2}{*}{$\begin{array}{l}\text { Total } \\
\mathbf{M}^{2}\end{array}$} & \multirow{2}{*}{$\begin{array}{c}\mathrm{MK}+\mathrm{MKA} \\
(\%)\end{array}$} & \multirow{2}{*}{ MK/MKA } & \multirow{2}{*}{$\begin{array}{c}\text { \%DiMK/ } \\
\text { TotalM }\end{array}$} & \multirow{2}{*}{ Azaphilones ${ }^{3}$} \\
\hline & MJA & MJ & MN & MLA & MX & MKA & $\mathrm{AML}$ & $\mathrm{CP}$ & MK & DiMK & DeML & DeMK & & & & & \\
\hline 1 & - & - & - & - & - & 0.49 & - & - & 1.33 & - & - & 0.02 & 1.84 & $1.82(98.9)$ & 2.7 & - & Mocusp, Mop B, Mo \\
\hline 2 & - & - & - & 0.04 & - & 0.82 & 0.20 & 0.03 & 6.77 & 0.21 & 0.05 & 0.68 & 8.80 & 7.59 (86.3) & 8.3 & 2.4 & \\
\hline 3 & - & - & - & - & - & 0.23 & 0.04 & 0.01 & 2.16 & 0.04 & 0.01 & 0.13 & 2.62 & 2.39 (91.2) & 9.4 & 1.5 & \\
\hline 4 & - & 0.01 & 0.02 & 0.01 & - & 0.10 & 0.04 & 0.03 & 0.48 & 0.11 & 0.02 & 0.29 & 1.11 & $0.58(52.3)$ & 4.8 & 9.9 & Mocusp \\
\hline 5 & - & 0.01 & 0.02 & 0.02 & - & 0.50 & 0.05 & 0.04 & 1.80 & 0.20 & 0.02 & 0.38 & 3.04 & $2.30(75.7)$ & 3.6 & 6.6 & Rubro, Moco, Mocusp, Mop B, Mo, Mof B, Mop A, Anka \\
\hline 6 & - & - & - & 0.03 & - & 0.31 & 0.08 & 0.03 & 2.05 & 0.11 & 0.03 & 0.27 & 2.91 & $2.36(81.1)$ & 6.6 & 3.8 & Mop B \\
\hline 7 & - & 0.06 & - & 0.06 & - & 0.37 & 0.19 & 0.08 & 2.22 & 0.20 & 0.06 & 0.85 & 4.09 & $2.59(63.3)$ & 6.0 & 4.9 & \\
\hline 8 & - & 0.02 & 0.09 & 0.12 & - & 2.13 & 0.18 & 0.28 & 6.26 & 0.59 & - & 0.16 & 9.83 & $8.39(85.4)$ & 2.9 & 6.0 & Cit, Rubro, Mocusp, Mof A, Mop B, Mo \\
\hline 9 & - & - & - & - & - & 0.13 & - & - & 4.17 & - & - & 0.28 & 4.58 & $4.30(93.9)$ & 32.1 & - & Mo, Anka \\
\hline 10 & - & 0.02 & - & 0.01 & - & 0.96 & 0.02 & 0.04 & 0.85 & 0.10 & 0.01 & 0.31 & 2.32 & $1.81(78.0)$ & 0.9 & 4.3 & Cit, Rubro, Mocusp, Mop B \\
\hline 11 & - & - & - & - & - & - & - & - & 0.07 & - & - & - & 0.07 & $0.07(100)$ & - & - & Rubro, Moco, Mop B, Mo, Mop A, Anka \\
\hline 12 & - & - & - & - & - & - & - & - & 0.08 & - & - & - & 0.08 & $0.08(100)$ & - & - & Rubro, PP-R, Moco, Mop B, Mo, Mof B, Mop A, Anka \\
\hline 13 & - & - & - & - & - & 0.62 & - & - & 23.18 & - & - & 0.04 & 23.84 & $23.80(99.8)$ & 37.4 & - & \\
\hline 14 & 0.03 & 0.05 & 0.07 & 0.04 & - & 0.27 & 0.18 & 0.08 & 2.19 & 0.23 & 0.06 & 0.56 & 3.76 & $2.46(65.4)$ & 8.1 & 6.1 & Mocusp, Mop B, Mo \\
\hline 15 & - & - & - & 0.19 & - & 1.33 & 0.86 & 0.58 & 8.27 & 1.16 & 0.16 & 1.44 & 13.99 & $9.60(68.6)$ & 6.2 & 8.3 & Rubro, Mocusp, Mof A, Mop B, Mo \\
\hline 16 & - & - & - & - & - & - & 0.02 & 0.02 & 0.33 & 0.01 & - & 0.03 & 0.41 & $0.33(80.5)$ & - & 2.4 & Rubro, PP-R, Moco, Mop B, Mo, Mof B, Mop A, Anka \\
\hline 17 & - & - & - & 0.03 & - & 0.16 & 0.12 & 0.16 & 1.09 & 0.13 & 0.02 & 0.15 & 1.86 & $1.25(67.2)$ & 6.8 & 7.0 & Mocusp, Mof A, Mop B, Mo \\
\hline 18 & - & - & - & - & - & 0.98 & - & - & 6.44 & 0.13 & - & 0.38 & 7.93 & $7.42(93.6)$ & 6.6 & 1.6 & Mocusp, Mop B, Mo \\
\hline 19 & - & 0.01 & - & 0.01 & - & 0.05 & 0.03 & 0.01 & 0.25 & 0.02 & 0.01 & 0.11 & 0.50 & $0.30(60.0)$ & 5.0 & 4.0 & \\
\hline 20 & - & - & - & - & - & 0.48 & - & - & 1.29 & - & - & 0.02 & 1.79 & $1.77(98.9)$ & 2.7 & - & Mocusp, Mop B, Mo \\
\hline 21 & - & 0.01 & 0.01 & 0.01 & - & 0.07 & 0.02 & - & 0.24 & 0.02 & 0.01 & 0.12 & 0.51 & $0.31(60.8)$ & 3.4 & 3.9 & \\
\hline 22 & - & - & - & 0.02 & - & 0.68 & 0.03 & 0.08 & 1.77 & 0.17 & 0.01 & 0.37 & 3.13 & $2.45(78.3)$ & 2.6 & 5.4 & Rubro, Mocusp, Mop B, Mo \\
\hline 23 & - & - & - & 0.04 & 0.01 & 0.68 & 0.05 & 0.10 & 8.47 & 0.17 & 0.03 & 0.23 & 9.78 & $9.15(93.6)$ & 12.5 & 1.7 & Rubro, Mocusp, Mop B, Mo \\
\hline 24 & - & - & - & - & - & 5.50 & - & - & 5.21 & - & - & 0.07 & 10.78 & $10.71(99.4)$ & 0.95 & - & \\
\hline 25 & - & 0.09 & 0.10 & 0.11 & 0.04 & 3.56 & 0.14 & 0.29 & 5.69 & 0.67 & 0.03 & 0.56 & 11.28 & $9.25(82.0)$ & 1.6 & 5.9 & Rubro, Mocusp, Mof A, Mop B, Mo \\
\hline 26 & - & - & - & $0.03_{5}$ & - & 0.39 & 0.10 & 0.04 & 3.52 & 0.15 & $0.03_{5}$ & 0.48 & 4.75 & $3.91(82.3)$ & 9.0 & 3.2 & Mocusp \\
\hline 27 & - & - & - & - & - & 0.61 & - & - & 2.68 & - & - & 0.09 & 3.38 & $3.29(97.3)$ & 4.4 & - & Mop B, Mo \\
\hline 28 & - & 0.03 & 0.04 & 0.04 & - & 0.41 & 0.07 & 0.05 & 0.98 & 0.15 & 0.02 & 0.32 & 2.11 & $1.39(65.9)$ & 2.4 & 7.1 & Mop B \\
\hline 29 & - & - & - & - & - & 0.01 & - & - & 0.08 & - & - & 0.04 & 0.13 & $0.09(69.2)$ & 8.0 & - & \\
\hline 30 & - & 0.02 & 0.03 & 0.02 & - & 0.37 & 0.05 & 0.02 & 2.19 & 0.07 & 0.02 & 0.30 & 3.09 & $2.56(82.8)$ & 5.9 & 2.3 & Mop B \\
\hline 31 & - & - & - & - & - & 0.31 & 0.04 & 0.03 & 0.85 & 0.07 & 0.01 & 0.12 & 1.43 & $1.16(81.1)$ & 2.7 & 4.9 & Rubro, Mop B, Mo, Anka \\
\hline
\end{tabular}

${ }^{1}$ Monacolins are listed in increasing order of elution times. MJ, MN, MX, ML, MK: monacolins J, N, X, L, K; MJA, MLA, MKA: monacolins J, L, K in hydroxyl acid forms; CP: compactin; DiMK: dihydromonacolin K; DeML, DeMK: dehydromonacolins L,K. ${ }^{2}$ TotalM: total monacolins. ${ }^{3}$ Azaphilones are listed in increasing order of elution times. Anka: ankaflavin; Cit: citrinin; Mo: monascin; Moco: monascorubramine; Mocusp: monascuspiloin; Mof A, Mof B: monasfluore A, monasfluore B; Mop A, Mop B: monaphilone A, monaphilone B; PP-R: 7-(2-hydroxyethyl)-monascorubramine; Rubro: rubropunctamine. 

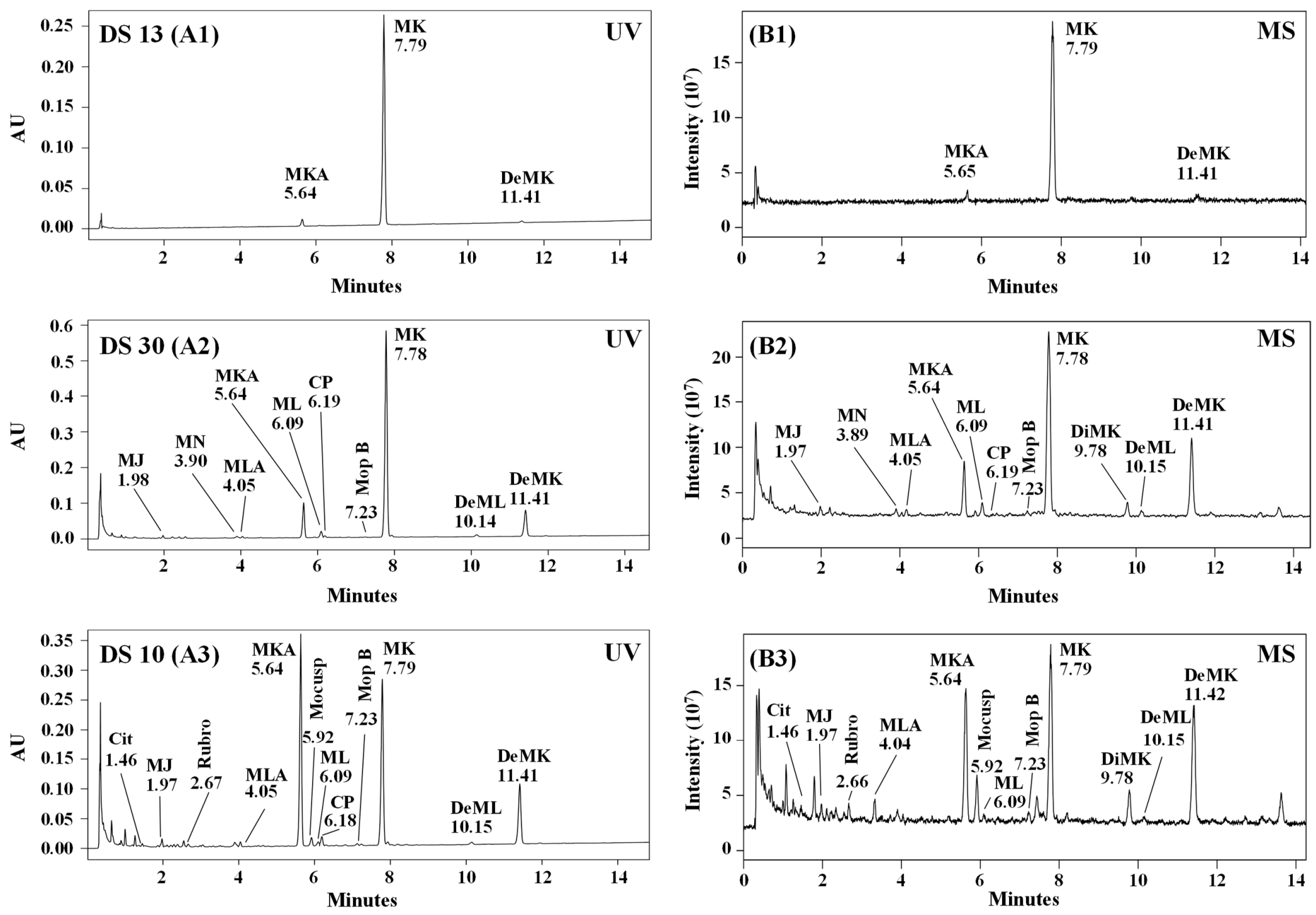

Figure 5. Cont. 

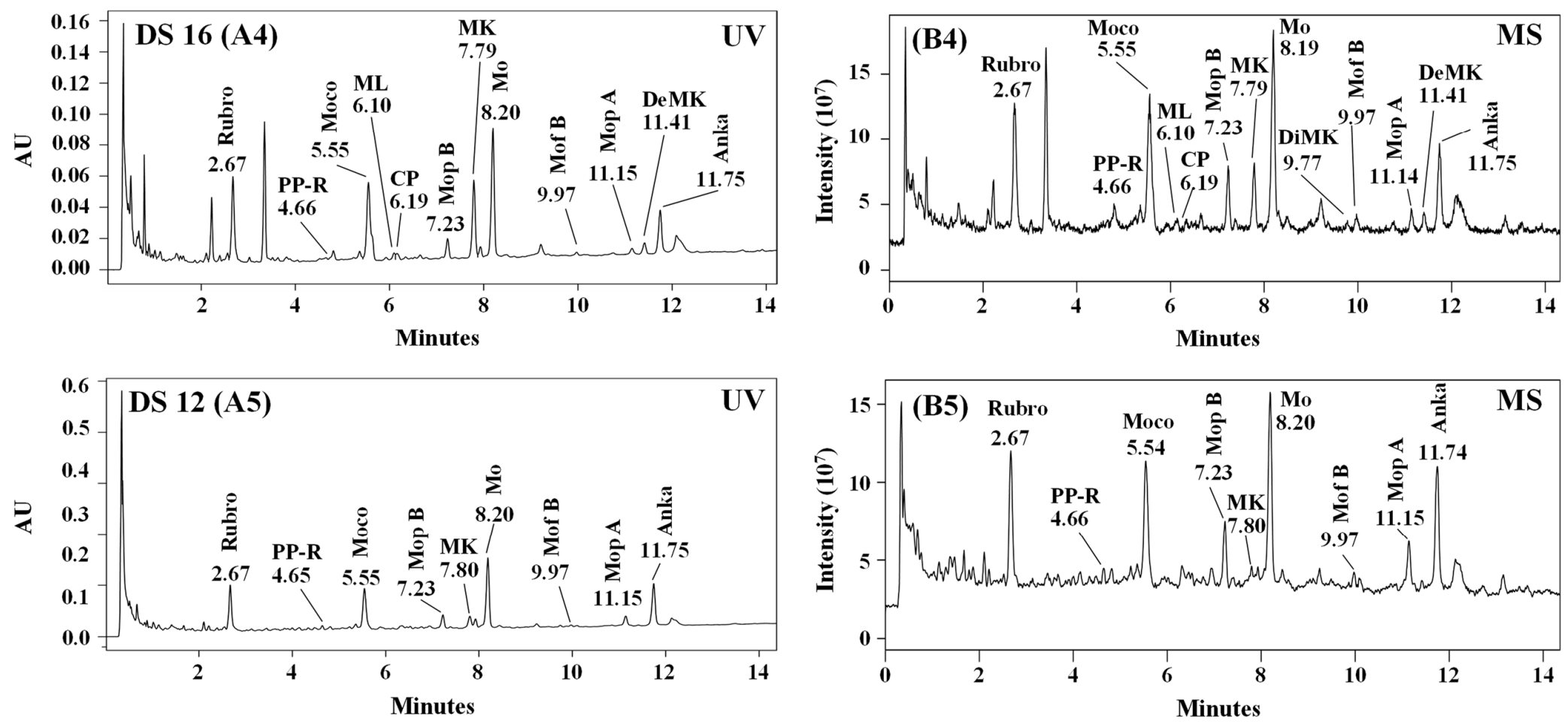

Figure 5. UHPLC chromatograms with UV detection at $238 \mathrm{~nm}$ (A1-A5) and full scan MS profile in positive ESI mode (B1-B5) of five characteristic RYR DS. MJ, MN, ML, MK: monacolins J, N, L, K; MLA, MKA: monacolins L, K in hydroxyl acid forms; CP: compactin; DiMK: dihydromonacolin K; DeML, DeMK: dehydromonacolins L,K; Anka: ankaflavin; Cit: citrinin; Mo: monascin; Moco: monascorubramine; Mocusp: monascuspiloin; Mof B: monasfluore B; Mop A and Mop B: monaphilone A and monaphilone B; PP-R: 7-(2-hydroxyethyl)-monascorubramine; Rubro: rubropunctamine. 
RYR formulation extracted. Considering the ratio between the mass of sample extracted and that of the formulation (tablet or powder in the capsule), the LOQ was estimated to be $\approx 0.9 \mu \mathrm{g}$ of lovastatin or other monacolins per capsule or tablet. The precision of the method was acceptable with a RSD for the replicates less than $2 \%$ (range $0.1 \%-1.9 \%$ ). The overall average value of RSD was $5 \%$ ranging between $2 \%$ and $11 \%$.

The amounts of the 12 monacolins identified in the 31 RYR DS are summarized in Table 5. There is a marked variability in total monacolins (TotalM), MK and MK + MKA contents per capsule or tablet with values ranging respectively between 0.07 and $23.84 \mathrm{mg}, 0.07$ and $23.18 \mathrm{mg}$ and 0.07 and $23.80 \mathrm{mg}$. MK is by far the main monacolin in the $31 \mathrm{RYR}$ analyzed representing $68 \%$ of TotalM (range $37-100 \%$ ) and the sum MK + MKA representing 82\% (range 52\%-100\%). As MKA is the active form of MK, the European Food Safety Authority (EFSA) considers that the effective MK content in RYR DS corresponds to the sum of both lactone and hydroxyl acid forms [38], which allows to get rid of the great variability of the ratio MK/MKA. Indeed, this ratio was comprised between 0.9 and 37 in 28 of the RYR DS analyzed in the present study and could not be determined for the three others due to the absence of MKA. These values are in agreement with literature data which report ranges from 0.4 to $85[10,12,13,39]$ while the ratio varies between 1.5 and 2 in properly prepared RYR [1]. Minor monacolins represent on average $18 \%$ of TotalM, ranging from 0 to $47 \%$. All these results fully confirm previous studies that showed that monacolin contents vary considerably in RYR end-use products, as they depend on the yeast strain and the fermentation process. For example, the HPLC analysis of 15 commercial tablets or capsules showed that TotalM ranges between 0.31 and $11.15 \mathrm{mg}$ per $600 \mathrm{mg}$ of RYR [39-42]. The literature review of the monacolins quantification established that MK represents $57 \%$ of TotalM $(n=26$; range $0 \%-99 \%)$, MK + MKA $83 \%(n=41$; range $32 \%-100 \%)$, and the minor monacolins $17 \%(n=41$; range $0 \%-68 \%)$ [1,10,39-43].

Our own results and all the literature data show that to improve the effectiveness and safety of RYR products in lowering/regulating cholesterol levels, a precise quantification of their monacolin content should be mandatory. Indeed, the MK content indicated for some formulations (18 over the 31 tested) is not sufficient to know the effectiveness of RYR DS as the amount of MKA, which is largely variable, is not specified. However, it is unclear if the term MK used by the manufacturers refers to the sole MK or to the sum MK + MKA. The chemical structures of MK and MKA being different, this should be mentioned. Moreover, the content of minor monacolins should be taken into account as they represent at least $\approx 14 \%$ of TotalM in $65 \%$ of the RYR tested in our study (Table 5 ) and in $71 \%$ of the 41 RYR products reported in the literature [1,10,39-43]. Indeed, if MK after its transformation by liver metabolism into MKA has the highest HMG-CoA reductase inhibitory activity, the other secondary monacolins such as CP, MJ, ML or DiMK are also active although at a lower or much lower extent (except for DiMK). Relative to MK or DiMK activity stated at 1, those of the other monacolins are 0.5 for CP and dihydroCP, 0.15 for ML, 0.2 for dihydroML, MX and dihydroMX, and 0.04 for MJ [44]. The dehydromonacolins, often considered as inactive, also present a low activity (0.2 for DeMK [45]).

\subsection{Comparison of ${ }^{1} H-N M R$ and UHPLC Results}

${ }^{1} \mathrm{H}-\mathrm{NMR}$ makes it possible to highlight the overall profile of the compounds present in the RYR DS in a single analysis of the crude extract. Indeed, not only all the monacolins, but also pigments (monascin and other pigments having the same skeleton), fatty acids (SFA and UFA), polyols (glycerol, sorbitol), glucose as well as various other products most often added to the formulation (piperine, carnitine, vitamins) are detected. The main drawback of the method is that the resonances identified are in most cases characteristic of a family of compounds and not of a specific compound as for example, monacolins with a hexahydronaphthalene ring and not only MK, or monascin and other pigments with the same skeleton and not the sole monascin. In contrast, the UHPLC-DAD-MS analysis allows a precise identification of the compounds, but like any separation technique, it requires much more time for implementation and especially the operating conditions used target certain structures of compounds, for example, here, monacolins and pigments. 
As the ${ }^{1} \mathrm{H}-\mathrm{NMR}$ resonances quantified are specific of monacolin families and not of each monacolin, the monacolin amounts determined by ${ }^{1} \mathrm{H}-\mathrm{NMR}$ must be compared to those obtained by UHPLC-DAD-MS for the same group of monacolins. The relationships between the amounts measured from the quantification of the resonances at $5.84 \mathrm{ppm}$ and $5.56 \mathrm{ppm}$ in 27 and 28 formulations respectively, both characteristic of all the monacolin structures except dihydromonacolins (TotalM-DiMK (because only this dihydromonacolin was detected by UHPLC)) (Table 3), and those obtained by UHPLC-DAD-MS for the same set of monacolins (Table 5) were very good, as demonstrated by slopes near 1, y-intercepts close to zero and correlation coefficients $\left(\mathrm{r}^{2}\right)$ greater than 0.99 for the two linear regression equations as well as p-values of 0.94 and 0.66 (Table S3). A similar very good correlation between NMR and UHPLC values was obtained when considering the mean concentrations measured from the two NMR resonances (Table S3).

The comparison of the contents of monacolins in lactone form determined from the quantification of their characteristic resonances at $4.60 \mathrm{ppm}$ and/or $4.25 \mathrm{ppm}$ in 22 RYR DS to those obtained by UHPLC-DAD-MS for the same panel of monacolins also showed results in good agreement. Indeed, the linear regression equation of the ${ }^{1} \mathrm{H}-\mathrm{NMR}$ and UHPLC values displayed a slope of 0.983 , a y-intercept of 0.013 and a correlation coefficient of 0.996 , and the $p$-value was 0.50 (Table S3). The resonance at $5.33 \mathrm{ppm}$ is characteristic of all the monacolins except MJ, MJA, ML, MLA and DiMK. Its quantification, which could only be performed on 17 RYR DS, led to values in agreement within $\pm 11 \%$ with those obtained by UHPLC for the same set of monacolins for only six (35\%) of them (Tables 3 and 5). The very weak relationship between the concentrations measured by the two methods was demonstrated by the low correlation coefficient $\left(r^{2}=0.723\right)$ and the y-intercept far from zero of the linear regression equation as well as a $p$-value of 0.02 representative of a significant difference between ${ }^{1} \mathrm{H}-\mathrm{NMR}$ and UHPLC data (Table S3). Therefore, for the RYR DS analyzed in this study, this resonance is unsuitable for quantification, in contrast to what was observed in a previous ${ }^{1} \mathrm{H}-\mathrm{NMR}$ assay of five formulations marketed for German consumers [18].

In the same way, the resonances at 4.05 and $3.63 \mathrm{ppm}$, characteristic of the monacolins in hydroxyl acid form, cannot be accurately quantified due to their strong overlap with matrix signals. Indeed, all the assays tentatively performed led to values considerably higher than those obtained by UHPLC for the same type of monacolins (data not shown).

From all the ${ }^{1} \mathrm{H}$ resonances characteristic of the various monacolin chemical structures, only those involving the hexahydronaphthalene ring (at 5.84 and $5.56 \mathrm{ppm}$ ) and the lactone ring (at 4.60 and $4.25 \mathrm{ppm}$ ) are appropriate for quantification without requiring curve deconvolution algorithms. It should be noted that the quantification of the resonances at 5.84 and $5.56 \mathrm{ppm}$ was hindered by the LOQ of the technique for three formulations (28/31 formulations were quantified), and that of resonances at 4.60 or/and $4.25 \mathrm{ppm}$ was additionally hampered by their overlap with matrix signals in some cases (only 22/31 formulations were quantified). To confirm that the ${ }^{1} \mathrm{H}-\mathrm{NMR}$ signals at 5.84 and $5.56 \mathrm{ppm}$ can be used to quantify the monacolin content in the RYR formulations, we compared the data obtained to TotalM determined by UHPLC (Table S3). The good relationship between the two sets of values (linear regression equation with a slope of 1.00 , a y-intercept at 0.113 and a correlation coefficient of 0.986 as well as a t-test $p$-value of 0.25 ) was not unexpected as DiMK (the sole dihydromonacolin detected in this study by UHPLC) represented $\approx 2.8 \%$ of the TotalM (range $0-9.9 \%$ ) (Table 5). The presence of DiMK was not surprising as it is produced in small quantities during the fermentation process of rice with Monascus $[1,23]$. In conclusion, ${ }^{1} \mathrm{H}-\mathrm{NMR}$ can be considered as a convenient method to determine the TotalM content in RYR DS.

\subsection{Quality Control Issues}

\subsubsection{About Monacolin Labelling of RYR DS}

Only 18 of the 31 RYR DS (58\%) tested specified a monacolin(s) content on their label: 14 indicated a level of MK, 1 the sum MK + MKA, and the label was imprecise for 3 DS, 1 indicating "Monascus 
purpureus" and 2 "monacolin" (Table 6). The amount of MK measured was in the range 90\%-110\% of declared amount for only 3 of the 14 DS mentioning a quantity of MK (DS 13, 23 and 27). If we hypothesize that the label "MK" includes MK + MKA, three additional DS (15, 22 and 24) were in the range $90 \%-110 \%$. If we consider that the claimed dose corresponds to TotalM for the three DS indicating "Monascus purpureus" (DS 4) or "monacolin" (DS 25 and 30), the measured amount was between $90 \%$ and $110 \%$ ( ${ }^{1} \mathrm{H}-\mathrm{NMR}$ and UHPLC mean amount for DS 25) (Table 6). So, 50\% of the formulations analyzed contained less than the declared amount of monacolin(s). It is also interesting to note that three DS (10, 11 and 12) contain a very small amount of MK (or MK + MKA) compared to the advertised dose (Table 6). It can thus be concluded that the monacolin label information is not reliable for many RYR products. This deviation between labelled and measured contents has already been reported by Mornar et al. [12] in five DS.

\subsubsection{About the Variability of Monacolins Consumed Per Day in RYR DS}

There is great variability in the daily consumption of monacolin amounts in terms of $\mathrm{MK}$, $\mathrm{MK}+\mathrm{MKA}$, and TotalM (or TotalM-DiMK) calculated from the UHPLC and ${ }^{1} \mathrm{H}-\mathrm{NMR}$ data taking into account the recommended serving(s) per day indicated on the labels of the RYR products (Table 6). The amounts of MK, MK + MKA and TotalM consumed daily ranged respectively between 0.08 and $46.2 \mathrm{mg}, 0.08$ and $47.6 \mathrm{mg}, 0.08$ and $47.7 \mathrm{mg}$ (UHPLC values) and 0.6 (the very low monacolin content in 3 samples (DS 11, 12 and 29) being undetected) and $47.8 \mathrm{mg}$ (NMR values). Although the range of monacolins consumed is the same considering MK, MK + MKA or TotalM, this is not true for all formulations. Indeed, MK represented less than $60 \%$ of TotalM in $45 \%$ (14/31) of the formulations analyzed and MK + MKA accounted for less than $80 \%$ of TotalM in $\approx 40 \%$, emphasizing the helpfulness of the NMR method which allows the content in all monacolins to be easily determined.

About half of the RYR DS analyzed $(48 \%, 15 / 31)$ contained more than $7 \mathrm{mg}$ of MK + MKA or $8 \mathrm{mg}$ of TotalM per recommended daily serving, whereas for $\approx 45 \%(14 / 31)$, the daily intake of MK $+\mathrm{MKA}$ or of TotalM was less than $\approx 3$ or $4 \mathrm{mg}$ respectively. Although only single batch formulations have been analyzed and the monacolin content may vary from batch to batch, the question of how effective these levels of monacolin can be for lowering/regulating cholesterol levels can be raised. In 2011, the EFSA concluded that a cause and effect relationship has been established between the consumption of $10 \mathrm{mg}$ per day of MK (sum of lactone and hydroxyl acid forms) from RYR DS and the maintenance of normal low-density lipoproteins-cholesterol (LDL-C) levels [38]. However, several clinical trials using RYR products at daily MK doses well below $10 \mathrm{mg}$ (around $5 \mathrm{mg}$ and even $3 \mathrm{mg}$ ) without any other cholesterol-lowering agents such as berberine, policosanol or garlic, showed a statistically significant reduction in LDL-C compared to placebo but these low values either corresponded to MK in the sole lactone form $[40,42]$ or it was not indicated whether they included the hydroxyl acid form of MK $[3,4,46]$. Nevertheless, when the RYR composition in monacolins was available, the amounts of $\mathrm{MK}+\mathrm{MKA}$ and TotalM were always at least around $7 \mathrm{mg}$ and $10 \mathrm{mg}$ respectively [40,42]. From these data, it can be concluded that a daily dietary intake of $\approx 7 \mathrm{mg}$ of $\mathrm{MK}+\mathrm{MKA}$ or $\approx 8 \mathrm{mg}$ of TotalM is sufficient to induce a cholesterol-lowering/regulating effect. On the other hand, the very low daily intake of monacolins found in $\approx 45 \%$ of the RYR DS analyzed might not lead per se to a significant reduction/regulation of cholesterol levels. 
Table 6. Comparison of the percentages of MK, MK + MKA and total monacolins per pill to monacolin labelling; amounts of MK, MK + MKA and total monacolins per recommended daily serving.

\begin{tabular}{|c|c|c|c|c|c|c|c|c|c|c|}
\hline \multirow{3}{*}{$\mathbf{N}^{\circ}$} & \multirow{3}{*}{$\begin{array}{c}\text { Amount of } \\
\text { Monacolin(s) Claimed } \\
\text { Per Pill (mg) }^{1}\end{array}$} & \multicolumn{4}{|c|}{ \% Measured/Claimed Per Pill } & \multirow{3}{*}{$\begin{array}{l}\text { Serving(s) } \\
\text { Per Day }{ }^{4}\end{array}$} & \multirow{3}{*}{$\begin{array}{c}\text { MK } \\
\text { Amount } \\
\text { (mg/day) }^{5}\end{array}$} & \multirow{3}{*}{$\begin{array}{c}\text { MK + MKA } \\
\text { Amount } \\
\text { (mg/day) }^{5}\end{array}$} & \multicolumn{2}{|c|}{$\begin{array}{l}\text { Total Monacolins } \\
\text { (mg/day) }{ }^{5}\end{array}$} \\
\hline & & \multirow{2}{*}{ MK $^{2}$} & \multirow{2}{*}{$\mathrm{MK}+\mathrm{MKA}^{2}$} & \multicolumn{2}{|c|}{ Total Monacolins $^{3}$} & & & & UHPLC $^{3}$ & $\mathrm{NMR}^{3}$ \\
\hline & & & & UHPLC & NMR & & & & & \\
\hline 1 & MK 2.6 & 51 & 70 & 71 & 65 & 1 & 1.3 & 1.8 & 1.8 & 1.7 \\
\hline 2 & MK + MKA 10.05 & 68 & 76 & 88 & 91 & 1 & 6.8 & 7.6 & 8.8 & 9.2 \\
\hline 3 & MK 2.8 & 77 & 85 & 94 & 110 & 3 & 6.5 & 7.2 & 7.9 & 9.2 \\
\hline 4 & M. purpureus $1.0^{6}$ & 48 & 58 & 109 & 99 & 3 & 1.4 & 1.7 & 3.3 & 3.0 \\
\hline 5 & & & & & & 1 & 1.8 & 2.3 & 3.0 & 2.5 \\
\hline 6 & MK 3.33 & 62 & 71 & 87 & 83 & 3 & 6.2 & 7.1 & 8.7 & 8.3 \\
\hline 7 & & & & & & 1 & 2.2 & 2.6 & 4.1 & 3.8 \\
\hline 8 & & & & & & 2 & 12.5 & 16.8 & 19.7 & 17.5 \\
\hline 9 & & & & & & 2 & 8.3 & 8.6 & 9.2 & 10.3 \\
\hline 10 & MK 9 & 9 & 20 & 26 & 23 & 4 & 3.4 & 7.2 & 9.3 & 8.3 \\
\hline 11 & MK 2.6 & 3 & 3 & 3 & & 4 & 0.3 & 0.3 & 0.3 & \\
\hline 12 & MK 2.6 & 3 & 3 & 3 & & 1 & 0.08 & 0.08 & 0.08 & \\
\hline 13 & MK 24.0 & 97 & 99 & 99 & 100 & 2 & 46.2 & 47.6 & 47.7 & 47.8 \\
\hline 14 & & & & & & 2 & 4.4 & 4.9 & 7.5 & 6.7 \\
\hline 15 & MK 9.6 & 86 & 100 & 146 & 126 & 1 & 8.3 & 9.6 & 14.0 & 12.1 \\
\hline 16 & & & & & & 2 & 0.7 & 0.7 & 0.8 & 0.6 \\
\hline 17 & & & & & & $2-3$ & $2.2-3.3$ & $2.5-3.8$ & $3.7-5.6$ & $3.0-4.5$ \\
\hline 18 & & & & & & 1 & 6.4 & 7.4 & 7.9 & 8.5 \\
\hline 19 & & & & & & $2-4$ & $0.5-1.0$ & $0.6-1.2$ & $1.0-2.0$ & $0.8-1.6$ \\
\hline 20 & MK 2.6 & 50 & 68 & 69 & 68 & 1 & 1.8 & 1.8 & 1.8 & 1.7 \\
\hline 21 & & & & & & $2-4$ & $0.5-1.0$ & $0.6-1.2$ & $1.0-2.0$ & $0.95-1.9$ \\
\hline 22 & MK 2.33 & 76 & 105 & 134 & 131 & 3 & 5.3 & 7.4 & 9.4 & 9.2 \\
\hline 23 & MK 9 & 94 & 102 & 109 & 118 & 1 & 8.5 & 9.2 & 9.8 & 10.6 \\
\hline 24 & MK 10.0 & 52 & 107 & 108 & 117 & 1 & 5.2 & 10.7 & 10.8 & 11.7 \\
\hline 25 & Monacolin 9.6 & 59 & 96 & 118 & 103 & 1 & 5.7 & 9.3 & 11.3 & 9.9 \\
\hline 26 & MK 5.0 & 70 & 78 & 95 & 91 & $1-2$ & $3.5-7.0$ & $3.9-7.8$ & $4.8-9.5$ & $4.5-9.1$ \\
\hline 27 & MK 2.6 & 103 & 126 & 130 & 153 & 1 & 2.7 & 3.3 & 3.4 & 4.0 \\
\hline 28 & & & & & & 1 & 1.0 & 1.4 & 2.1 & 1.7 \\
\hline 29 & & & & & & $2-4$ & $0.2-0.3$ & $0.2-0.4$ & $0.25-0.5$ & \\
\hline 30 & Monacolin 3.3 & 66 & 77 & 93 & 91 & 3 & 6.6 & 7.7 & 9.3 & 9.0 \\
\hline 31 & & & & & & 1 & 0.9 & 1.2 & 1.4 & 1.2 \\
\hline
\end{tabular}

${ }_{1}^{1}$ The exact monacolin labelling is indicated for each formulation. ${ }^{2}$ Percentages of MK and MK + MKA were calculated from amounts determined by UHPLC-DAD-MS (see Table 5 ). ${ }^{3}$ Percentages of total monacolins determined by UHPLC-DAD-MS and ${ }^{1} \mathrm{H}-\mathrm{NMR}$ correspond, respectively, to TotalM and TotalM-DiMK (see Tables 3 and 5). ${ }^{4}$ Serving(s) recommended per day on the label. ${ }^{5}$ Amounts of MK, MK + MKA and total monacolins per recommended daily serving. ${ }^{6}$ The exact label is: 750 mg of organic RYR titrated at $0.4 \%$ of Monascus purpureus for three pills. 


\section{Materials and Methods}

\subsection{Red Yeast Rice Dietary Supplements}

Thirty-one RYR DS bought mainly on internet web sites (24) but also from local health food stores (7) between September 2013 and June 2014 were analyzed before their expiration date with UHPLC and ${ }^{1} \mathrm{H}-\mathrm{NMR}$ techniques. RYR products were formulated as capsules (20) or tablets (11). All samples with their name, origin, form, batch number, expiration date and RYR extract content are listed in Table 1.

\subsection{Chemicals and Reagents}

Authentic standards of lovastatin (MK), citrinin and monascin were purchased from Sigma Aldrich (St. Louis, MO, USA) and those of DeMK, CP and DiMK from TRC (North York, ON, Canada). All other chemicals and reagents used as well the NMR reference for internal chemical shift and quantification (sodium 2,2,3,3-tetradeutero-3-(trimethylsilyl) propanoate (TSP)) were supplied from Sigma Aldrich (St. Louis, MO, USA). Deuterated solvents were obtained from Euriso-Top (91194 Saint Aubin, France). MKA was prepared by hydrolyzing a solution of standard lovastatin in acetonitrile:water $\left(\mathrm{CH}_{3} \mathrm{CN}: \mathrm{H}_{2} \mathrm{O}\right)$ or deuterated acetonitrile:deuterated water $\left(\mathrm{CD}_{3} \mathrm{CN}: \mathrm{D}_{2} \mathrm{O}\right) 80: 20 v / v\left(3.7 \mathrm{mg} \mathrm{mL}^{-1}\right)$ with a $1 \mathrm{M} \mathrm{NaOH}$ or $\mathrm{NaOD}$ solution under the optimized conditions described in literature [12]. The complete conversion of the lactone form (MK) to its acidic form (MKA) was confirmed by HPLC-MS as the $[\mathrm{M}+\mathrm{H}]^{+}$peak of MK at $m / z 405$ disappeared and the peak of MKA at $m / z 423$ was sole detected. Demineralized water was obtained with a Milli-Q system Purelab flex Veolia Waters.

\subsection{Choice of Extraction Solvent and Preparation of Samples for Analyses}

The extraction of monacolins from RYR bulk powders with various solvents such as $\mathrm{CH}_{3} \mathrm{OH}$, ethanol: water mixtures, $\mathrm{CH}_{3} \mathrm{CN}$ or ethyl acetate has been extensively described, the best results being obtained with $\mathrm{CH}_{3} \mathrm{OH}$ or ethanol:water 75:25 [11-13,47,48]. Two extraction solvents were tested in this study, $\mathrm{CH}_{3} \mathrm{OH}$ and $\mathrm{CH}_{3} \mathrm{CN}: \mathrm{H}_{2} \mathrm{O}$ 80:20 (because the $\mathrm{MK}$ solubility in $\mathrm{CH}_{3} \mathrm{CN}$ is higher than in ethanol, 28 and $16 \mathrm{mg} \mathrm{mL}^{-1}$ respectively) and led to the almost same extraction recovery for all compounds, as measured by UHPLC-DAD. In this study, all sample extractions were performed with the mixture $\mathrm{CH}_{3} \mathrm{CN}: \mathrm{H}_{2} \mathrm{O}$ (or $\mathrm{CD}_{3} \mathrm{CN}: \mathrm{D}_{2} \mathrm{O}$ ).

For the qualitative ${ }^{1} \mathrm{H}-\mathrm{NMR}$ analysis, around $100 \mathrm{mg}$ of the powdered RYR samples were mixed with $1 \mathrm{~mL}$ of $\mathrm{CD}_{3} \mathrm{CN}: \mathrm{D}_{2} \mathrm{O}(80: 20 \mathrm{v} / \mathrm{v})$ under vortex agitation for $1 \mathrm{~min}$ and then sonicated for $10 \mathrm{~min}$. The suspension was then centrifuged ( $5 \mathrm{~min}, 3000 \mathrm{rpm}$ ) and $700 \mu \mathrm{L}$ of the supernatant analyzed. TSP as internal chemical shift $(\delta)$ reference was added before NMR recording.

For the quantitative ${ }^{1} \mathrm{H}-\mathrm{NMR}$ analysis, between 20 and $100 \mathrm{mg}$ of powdered sample was exactly weighed and mixed with $1 \mathrm{~mL}$ of $\mathrm{CD}_{3} \mathrm{CN}: \mathrm{D}_{2} \mathrm{O}(80: 20 v / v)$ under magnetic stirring during 20 min, then sonicated for $10 \mathrm{~min}$. After centrifugation ( $5 \mathrm{~min}, 3000 \mathrm{rpm}), 30 \mu \mathrm{L}$ of a $10.0 \mathrm{mM}$ solution of TSP were added to $800 \mu \mathrm{L}$ of supernatant and the resulting solution was analyzed. The final concentration of TSP was $0.36 \mathrm{mM}$.

The efficacy of this single-step extraction procedure was demonstrated in samples with low and high contents of monacolins. Around 30,85 and $90 \mathrm{mg}$ accurately weighed of three different powdered samples (respectively DS 13, 22 and 5) were extracted as described above, except that after centrifugation, the whole supernatant was carefully collected and analyzed by ${ }^{1} \mathrm{H}-\mathrm{NMR}$. The exactly weighed residual wet pellet was re-extracted with the same protocol than above and the supernatant analyzed using ${ }^{1} \mathrm{H}-\mathrm{NMR}$. In the second extraction, the amounts of monacolins found were respectively $\approx 4.7 \%, 8.0 \%$ and $14.0 \%$ of that measured in the first extract. However, the solvent present in the wet pellet represented respectively at least (as the total weight of the powdered sample used was subtracted from the pellet weight $) \approx 5.4 \%, 8.3 \%$ and $14.0 \%$ of the initial solvent weight $(1 \mathrm{~mL}=905.48 \mathrm{mg})$. The amount of monacolins extracted was thus directly proportional to the amount of solvent remaining in the pellet. So, all the monacolins were dissolved in the solvent $(1 \mathrm{~mL})$ used in the single-step extraction procedure and were thus quantified. 
For the quantitative analysis by UHPLC, between 10 and $100 \mathrm{mg}$ of each powdered sample was exactly weighed and mixed with $1 \mathrm{~mL}$ of $\mathrm{CH}_{3} \mathrm{CN}: \mathrm{H}_{2} \mathrm{O}(80: 20 \mathrm{v} / \mathrm{v})$ under magnetic stirring during $20 \mathrm{~min}$, then sonicated for $10 \mathrm{~min}$. The suspension was then centrifuged ( $5 \mathrm{~min}, 3000 \mathrm{rpm})$. The supernatant was filtered through a $0.45 \mu \mathrm{m}$ pore size filter before the injection.

\section{4. ${ }^{1} \mathrm{H}-\mathrm{NMR}$ Analysis}

\subsubsection{Recording Conditions}

For the qualitative analysis, the $1 \mathrm{D}^{1} \mathrm{H}-\mathrm{NMR}$ experiments were performed on a Bruker Avance 500 spectrometer (Bruker Biospin AG, Fallanden, Switzerland) equipped with a $5 \mathrm{~mm}{ }^{1} \mathrm{H}$-optimized triple resonance NMR inverse helium-cooled probe (TCI CryoProbe) at $298 \mathrm{~K}$ (standard ${ }^{1} \mathrm{H}$ sensitivity for $0.1 \%$ ethylbenzene in $\mathrm{CDCl}_{3}$ : SNR 4200). Typical acquisition parameters were as follows: spectral width $8000 \mathrm{~Hz}, 32 \mathrm{~K}$ data points, pulse width $10.0 \mu$ s (flip angle $90^{\circ}$ ), acquisition time $2.04 \mathrm{~s}$, relaxation delay $1 \mathrm{~s}$, number of scans 16 , corresponding to a recording time of $0.8 \mathrm{~min}$.

For the quantitative $1 \mathrm{D}^{1} \mathrm{H}-\mathrm{NMR}$ experiments, analyses were acquired on a Bruker Avance 400 spectrometer equipped with a TBO (Triple resonance Broadband Observe) probe at $298 \mathrm{~K}$ (standard ${ }^{1} \mathrm{H}$ sensitivity for $0.1 \%$ ethylbenzene in $\mathrm{CDCl}_{3}$ : $\mathrm{SNR} 266$ ). The spectra were recorded with the following parameters: spectral width $8000 \mathrm{~Hz}, 64 \mathrm{~K}$ data points, pulse width $3.7 \mu$ s (flip angle $\approx 30^{\circ}$ ), acquisition time $5.12 \mathrm{~s}$, and relaxation delay $4.88 \mathrm{~s}$. The number of scans was 64 or 512 for recording times of $\approx 11$ or 85 min respectively. Three different samples of the same DS were analyzed.

$\mathrm{T}_{1}$ relaxation times of the methyl protons of TSP and those of the characteristic monacolin protons used for quantification (ethylenic protons of the hexahydronaphthalene ring ( $\mathrm{H} 6$ and $\mathrm{H} 4$ ) and of the unsaturated lactone of dehydromonacolin derivatives ( $\mathrm{H} 22)$, and $\mathrm{CH}-\mathrm{OH}$ proton of the lactone ring (H22)) (see Table 2 for proton numbering) were measured in RYR DS by the inversion-recovery pulse sequence method. Twenty delays from 0.001 to $30 \mathrm{~s}$ were used with an acquisition time of $2.56 \mathrm{sec}$ and a relaxation delay of $30 \mathrm{~s}$. The $\mathrm{T}_{1} \mathrm{~s}$ found were between 1.6 and $2.2 \mathrm{~s}$ for monacolin derivatives and $4.5 \mathrm{~s}$ for TSP. All the ${ }^{1} \mathrm{H}$ resonances were thus considered as fully relaxed since more than $98 \%$ of the signal intensity of the TSP protons was recovered in the recording conditions used.

The concentrations were calculated by comparing the signal areas of convenient protons of targeted compounds with those of TSP, the area of each NMR peak being directly proportional to the number of corresponding nuclei in fully relaxed recording conditions.

Data were processed with the Bruker TopSpin software 2.1 or 3.1 with one level of zero-filling and Fourier transformation after multiplying FIDs by an exponential line-broadening function of $0.3 \mathrm{~Hz}$. Assignment of signals of MK, MKA, CP and DiMK was achieved with $1 \mathrm{D}^{13} \mathrm{C}-\mathrm{NMR}$ and $2 \mathrm{D}$ experiments (gCOSY, gHSQC and gHMBC).

\subsubsection{Quantification}

The quantification was performed on the characteristic ${ }^{1} \mathrm{H}-\mathrm{NMR}$ signals $(\mathrm{CH}=, \mathrm{CH}-\mathrm{OH}$ and $\mathrm{CH}-\mathrm{OR}$ ) of the different monacolin families (monacolins in lactone and hydroxyl acid forms, dehydromonacolins and dihydromonacolins). The amount of compound (mg) per dosage unit is calculated from the following equation:

$$
Q=\frac{A_{i}}{A_{T S P}} \times \frac{N b_{T S P}}{N b_{i}} \times C_{T S P} \times \frac{V_{2}}{V_{1}} \times V_{t} \times M \times \frac{m_{t}}{m}
$$

with $A_{i}$ and $A_{T S P}$ being the integrated areas of the characteristic NMR signal(s) of the monacolins to be quantified (i) and of the TSP signal respectively, $N b_{i}$ and $N b_{T S P}$ the number of protons contributing to the signal of the analyte and of TSP ( 9 protons), $C_{T S P}$ the concentration of TSP in the solution analyzed, $V_{1}$ the volume of supernatant analyzed, $V_{2}$ the volume of solution analyzed $\left(V_{1}+V_{T S P}(30 \mu \mathrm{L})\right), V_{t}$ the volume used to dissolve the sample $(1 \mathrm{~mL}), M$ the molecular weight of the analyte, $m_{t}$ and $m$ the weights of the dosage unit (tablet or powder from capsule) and of the sample analyzed. As NMR 
did not allow to characterize individually all the monacolins present in RYR, the molecular weight considered was that of MK, the main one. This led to an approximation less than $\pm 5 \%$ for MKA, DeMK, MX, DiMK and CP but higher for other monacolins, $+10 \%$ for MN, $+16 \%$ for MJA, $\approx+20 \%$ for MJ and MLA, $+25 \%$ for ML and $+29 \%$ for DeML (see Figure 2 for chemical structures). Nevertheless, all the monacolins whose molecular weight differs of more than $5 \%$ relative to MK, are very minor. From their amounts determined by UHPLC, we found that the approximation on their molecular weights led to an increase of the total content of monacolins determined by NMR of less than $3 \%(<1 \%$ for 22 DS, between 1 and $2.2 \%$ for 8 others, and $2.6 \%$ for one formulation).

\subsection{UHPLC-DAD-MS Analysis}

\subsubsection{Instrumentation}

The liquid chromatographic system was a Waters Acquity UPLC-DAD-SQD (Ultra Performance Liquid Chromatography with Diode Array Detector and Single Quadrupole Detector). It consists of the following modular components: a binary pump, an automatic sample injector with two 48-well trays, a column oven, a diode array detector and a simple quadrupole detector with ESI. All the analyses were performed using ESI ionization with the following settings: positive mode, electrospray source temperature $135^{\circ} \mathrm{C}$, desolvatation temperature $300^{\circ} \mathrm{C}$, capillary voltage $2.8 \mathrm{kV}$, cone voltage $3 \mathrm{~V}$, extractor voltage $2.0 \mathrm{~V}$ and RF lens voltage $0.1 \mathrm{~V}$. The full scan mass spectra were acquired over a range of $m / z$ 100-1000. The separations were achieved on a Kinetex C18 (100 mm $\times 2.1 \mathrm{~mm}$, particle size $1.7 \mu \mathrm{m}$ ) column. The mobile phase consisted of water with $0.02 \%$ formic acid (solvent $\mathrm{A}$ ) and acetonitrile with $0.02 \%$ formic acid (solvent $\mathrm{B}$ ) at a flow rate of $0.6 \mathrm{~mL} \mathrm{~min}{ }^{-1}$. The temperature of the column oven was set at $40{ }^{\circ} \mathrm{C}$. The chromatographic analysis consisted of an isocratic elution with a $65 \% \mathrm{~A} / 35 \% \mathrm{~B}$ mixture for $0.5 \mathrm{~min}$ followed by a linear gradient program: from $65 \% \mathrm{~A} / 35 \% \mathrm{~B}$ to $35 \%$ $\mathrm{A} / 65 \% \mathrm{~B}$ between 0.5 and $15 \mathrm{~min}$ and finally to $0 \% \mathrm{~A} / 100 \% \mathrm{~B}$ over $3 \mathrm{~min}$. After each run, the percentage of solvents ramped to their initial composition in $1 \mathrm{~min}$ and then the column was re-equilibrated for $2 \mathrm{~min}$. The UV detection and quantification were performed at $238 \mathrm{~nm}$ and UV-Vis spectra were recorded within a range of $200-800 \mathrm{~nm}$. The data acquisition and processing were done with the Empower 2 software.

\subsubsection{Validation Procedure}

The UHPLC-UV method described was validated in terms of system suitability, linearity, precision, sensitivity (LOD, LOQ) and specificity.

The system suitability tests to ensure the reproducibility of the chromatographic system were performed by injecting six times $1 \mu \mathrm{L}$ of a solution of standard lovastatin. The RSD found was $0.2 \%$ for a $0.42 \mathrm{mg} \mathrm{mL}^{-1}$ solution and $1.5 \%$ for a $4.2 \times 10^{-3} \mathrm{mg} \mathrm{mL}^{-1}$ solution and was acceptable as it was less than $2 \%$ [13].

The linearity of the UHPLC-UV assay was tested for eight concentration levels of standard lovastatin in the range $4.18 \times 10^{-3}-0.42 \mathrm{mg} \mathrm{mL}^{-1}$ in $\mathrm{CH}_{3} \mathrm{CN}: \mathrm{H}_{2} \mathrm{O}(80: 20 \mathrm{v} / \mathrm{v})$. The correlation coefficient value $\left(\mathrm{r}^{2}=0.9993\right)$ of the calibration curve obtained by plotting the peak areas versus concentrations indicated satisfactory linearity of the method in the range studied. All the monacolins with a characteristic UV maximum absorption peak at $\approx 238 \mathrm{~nm}$ were quantified using the calibration curve established for standard lovastatin and their amounts in mg calculated considering their respective molecular weights. DiMK was not detected at this wavelength and was thus quantified by MS from its $[\mathrm{MH}]^{+}$peak area by comparison to that of MK whose amount was previously determined by UV, considering that their ionization efficiencies were similar.

Each solution of extracted RYR sample was analyzed three times. Two independently prepared samples were analyzed for 18 RYR DS and three for the other 13. 
The specificity of the method, under the conditions described above, was verified using the chromatographic peak purity tool included in the Empower 2 software and showed no co-elution between peaks of monacolins and those of the complex matrix.

\subsection{High-Resolution Mass Spectrometry (HR-MS) Experiments}

HR-MS and HR-MS/MS were performed on a Waters Xevo G2 QTOF mass spectrometer (Waters, Manchester, UK) with ESI in positive mode $\left(\mathrm{ESI}^{+}\right)$and in few cases in negative mode $\left(\mathrm{ESI}^{-}\right)$. For both modes, the instrument parameters were as follows: for MS analysis, cone voltage 30 or $50 \mathrm{~V}$, source temperature $110{ }^{\circ} \mathrm{C}$, desolvatation temperature $300{ }^{\circ} \mathrm{C}$, cone gas flow rate $20 \mathrm{~L} \mathrm{~h}^{-1}$, scan range $\mathrm{m} / \mathrm{z}$ 50-1200; for MS/MS analysis, three collision energies were used 15, 25 and $35 \mathrm{~V}$ with the cone voltage maintained at $30 \mathrm{~V}$ or $50 \mathrm{~V}$ and the spectra were acquired with a mass precursor ion selection of $3 \mathrm{Da}$. All analyses were performed using the lockspray, which ensured accuracy and reproducibility. Leucine

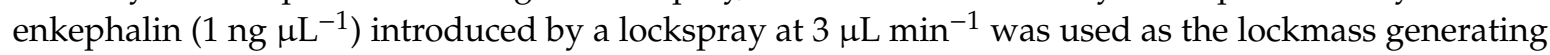
reference ions at $m / z 556.2771$ or 554.2615 in positive or negative mode respectively. The MassLynx software was used to calculate the most probable chemical formula and the theoretical exact mass of the molecular and fragment ions by comparison with their measured accurate ionic masses.

\subsection{Statistical Analysis}

Comparison of quantitative determination of the different monacolin sets obtained by ${ }^{1} \mathrm{H}-\mathrm{NMR}$ and UHPLC was performed (i) by simple linear regression and (ii) with the Wilcoxon signed-rank test, a non-parametric test that can be used as an alternative to the paired Student's t-test for matched pairs when the population cannot be assessed to be normally distributed; the $p$-values $>0.05$ (95\% confidence level) were considered as proofs of no significant difference between the values measured by the two methods.

\section{Conclusions}

This work demonstrated that ${ }^{1} \mathrm{H}-\mathrm{NMR}$ is a powerful method to establish rapidly $(<1 \mathrm{~min})$ the spectral signature of RYR DS and to afford the quantitative determination of their total monacolin content in a reasonable recording time (from $\approx 10$ to 90 min depending on their concentration in the solution analyzed). The method was validated against UHPLC-DAD-MS, the gold standard technique for a detailed determination of all the monacolins existing in RYR products. Indeed, the quantification of the ${ }^{1} \mathrm{H}$ resonances of the hexahydronaphthalene ring at 5.84 and $5.56 \mathrm{ppm}$, characteristic of all the monacolin families except the dihydomonacolins present in very low amounts, led to values in close agreement with those of all the monacolins, including dihydromonacolins, measured by UHPLC. These two resonances did not overlap with matrix signals in the RYR DS tested and their quantification is only limited by the sensitivity of the method ( $\mathrm{LOQ} \approx 0.25 \mathrm{mg}$ per capsule or tablet in our recording conditions). Therefore, ${ }^{1} \mathrm{H}-\mathrm{NMR}$ can be considered as an accurate method for determining the total monacolin content of RYR DS, not only those of the main ingredients MK and MKA, but also of minor monacolins which are also active HMG-CoA reductase inhibitors although generally less potent, accounting for a non-negligible amount (mean of $\approx 18 \%$ ) of TotalM. Taking into account the easy preparation of the RYR DS for the analysis (a simple extraction of capsule/tablet powder by an adequate deuterated solvent), ${ }^{1} \mathrm{H}$-NMR can be proposed as a high-throughput (thanks to commonly used sample changers) screening method for quality control of RYR formulations on the market. Indeed, the product labels are often incomplete and inappropriate: $42 \%$ of the RYR DS analyzed in this study did not provide information on the concentration of monacolins; when the label mentioned MK, it was not specified whether the amount of MK included or not MKA; the amount of the other minor monacolins was never indicated. The deviation between labelled and measured contents must also be emphasized: only $50 \%$ of the labelled formulations actually contained the declared amount of monacolin(s). In conclusion, health authorities should impose to manufacturers a strict control of 
the quality of the RYR DS to assess the ability of the marketed RYR products in reducing/regulating cholesterol level.

Supplementary Materials: The following are available online, Table S1: ${ }^{1} \mathrm{H}$ and ${ }^{13} \mathrm{C}-\mathrm{NMR}$ data (solvent: $\mathrm{CD}_{3} \mathrm{CN}: \mathrm{D}_{2} \mathrm{O}$ 80:20) of monacolin $\mathrm{K}$ in lactone (MK) and hydroxyl acid (MKA) forms, compactin and dihydromonacolin K. Table S2: ${ }^{1} \mathrm{H}-\mathrm{NMR}$ quantitative determination of monacolins in RYR dietary supplements. Table S3: Comparison of monacolin amounts measured in RYR dietary supplements by ${ }^{1} \mathrm{H}-\mathrm{NMR}$ and UHPLC. Figure S1: ${ }^{1} \mathrm{H}-\mathrm{NMR}$ spectra $\left(\mathrm{CD}_{3} \mathrm{CN}: \mathrm{D}_{2} \mathrm{O}(80: 20)\right)$ of all the dietary supplements analyzed in the present study. Upper part: entire spectrum, lower part: enlarged downfield region (4-9 ppm). Figure S2: UHPLC chromatograms with UV detection at $238 \mathrm{~nm}$ (A) and full scan MS profile in positive ESI mode (B) of 9 RYR dietary supplements.

Author Contributions: Conceptualization, M.M.-M.; methodology, R.H., G.A., S.B., N.M.-F.; validation, R.H., G.A., S.B.; formal analysis, S.B.; investigation, R.H., G.A., S.B., N.M.-F.; writing—original draft preparation, R.H., V.G.; writing-review and editing, R.M., M.M.-M.; visualization, V.G., S.B., M.M.-M.; supervision, M.M.-M.; funding acquisition, M.M-M., V.G. All authors have read and agreed to the published version of the manuscript.

Funding: This research was funded by the French National Agency for the Safety of Medicines and Health Products (Agence Nationale de Sécurité du Médicament et des produits de santé: ANSM), grant AAP-2012-082, (convention ANSM/UPS n ${ }^{\circ} 2012 S 071$ ).

Acknowledgments: The authors wish to thank Isabelle Fabing from the SPCMIB lab and the Integrated Screening Platform of Toulouse for support with chromatography.

Conflicts of Interest: The authors declare no conflict of interest. The funders had no role in the design of the study; in the collection, analyses, or interpretation of data; in the writing of the manuscript, or in the decision to publish the results.

\section{References}

1. Ma, J.; Li, Y.; Ye, Q.; Li, J.; Hua, Y.; Ju, D.; Zhang, D.; Cooper, R.; Chang, M. Constituents of red yeast rice, a traditional Chinese food and medicine. J. Agric. Food Chem. 2000, 48, 5220-5225. [CrossRef]

2. Wang, T.-H.; Lin, T.-F. Monascus rice products. Adv. Food Nutr. Res. 2007, 53, 123-159.

3. Li, Y.; Jiang, L.; Jia, Z.; Xin, W.; Yang, S.; Yang, Q.; Wang, L. A meta-analysis of red yeast rice: An effective and relatively safe alternative approach for dyslipidemia. PLoS ONE 2014, 9, e98611. [CrossRef]

4. Gerards, M.C.; Terlou, R.J.; Yu, H.; Koks, C.H.W.; Gerdes, V.E.A. Traditional Chinese lipid-lowering agent red yeast rice results in significant LDL reduction but safety is uncertain-A systematic review and meta-analysis. Atherosclerosis 2015, 240, 415-423. [CrossRef] [PubMed]

5. Chen, C.-H.; Yang, J.-C.; Uang, Y.-S.; Lin, C.-J. Improved dissolution rate and oral bioavailability of lovastatin in red yeast rice products. Int. J. Pharm. 2013, 444, 18-24. [CrossRef] [PubMed]

6. ANSES, OPINION of the French Agency for Food, Environmental and Occupational Health \& Safety on the Risks Associated with the Presence of "Red Yeast Rice" in Food Supplements. 2014. Available online: https://www.anses.fr/fr/system/files/NUT2012sa0228EN.pdf (accessed on 9 September 2019).

7. Mazzanti, G.; Moro, P.A.; Raschi, E.; Da Cas, R.; Menniti-Ippolito, F. Adverse reactions to dietary supplements containing red yeast rice: Assessment of cases from the Italian surveillance system. Br. J. Clin. Pharmacol. 2017, 83, 894-908. [CrossRef] [PubMed]

8. EFSA Panel on Food Additives and Nutrient Sources added to Food (ANS). Scientific opinion on the safety of monacolins in red yeast rice. EFSA J. 2018, 16, 5368. [CrossRef]

9. Red Yeast Rice-An Update Overview of the Reported ADRs. Netherlands Pharmacovigilance Centre Lareb. Available online: https://www.lareb.nl/media/3204/signals_2019_rode-gistrijst_nvwa-update.pdf (accessed on 9 January 2020).

10. Li, Y.-G.; Zhang, F.; Wang, Z.-T.; Hu, Z.-B. Identification and chemical profiling of monacolins in red yeast rice using high-performance liquid chromatography with photodiode array detector and mass spectrometry. J. Pharm. Biomed. Anal. 2004, 35, 1101-1112. [CrossRef]

11. Wu, C.-L.; Kuo, Y.-H.; Lee, C.-L.; Hsu, Y.-W.; Pan, T.-M. Synchronous high-performance liquid chromatography with a photodiode array detector and mass spectrometry for the determination of citrinin, monascin, ankaflavin, and the lactone and acid forms of monacolin $\mathrm{K}$ in red mold rice. J. AOAC Int. 2011, 94, 179-190.

12. Mornar, A.; Sertic, M.; Nigovic, B. Development of a rapid LC/DAD/FLD/MS ${ }^{\mathrm{n}}$ method for the simultaneous determination of monacolins and citrinin in red fermented rice products. J. Agric. Food Chem. 2013, 61, 1072-1080. [CrossRef] 
13. Avula, B.; Cohen, P.A.; Wang, Y.H.; Sagi, S.; Feng, W.; Wang, M.; Zweigenbaum, J.; Shuangcheng, M.; Khan, I.A. Chemical profiling and quantification of monacolins and citrinin in red yeast rice commercial raw materials and dietary supplements using liquid chromatography-accurate QToF mass spectrometry: Chemometrics application. J. Pharm. Biomed. Anal. 2014, 100, 243-253. [CrossRef] [PubMed]

14. Song, F.; El-Demerdash, A.; Lee, S.-J.S.H.; Smith, R.E. Fast screening of lovastatin in red yeast rice products by flow injection tandem mass spectrometry. J. Pharm. Biomed. Anal. 2012, 57, 76-81. [CrossRef] [PubMed]

15. Svoboda, P.; Sander, D.; Plachká, K.; Nováková, L. Development of matrix effect-free MISPE-UHPLC-MS/MS method for determination of lovastatin in Pu-erh tea, oyster mushroom, and red yeast rice. J. Pharm. Biomed. Anal. 2017, 140, 367-376. [CrossRef] [PubMed]

16. Malet-Martino, M.; Holzgrabe, U. NMR techniques in biomedical and pharmaceutical analysis. J. Pharm. Biomed. Anal. 2011, 55, 1-15. [CrossRef] [PubMed]

17. Simmler, C.; Napolitano, J.G.; McAlpine, J.B.; Chen, S.-N.; Pauli, G.F. Universal quantitative NMR analysis of complex natural samples. Curr. Opin. Biotechnol. 2014, 25, 51-59. [CrossRef]

18. Lachenmeier, D.W.; Monakhova, Y.B.; Kuballa, T.; Löbell-Behrends, S.; Maixner, S.; Kohl-Himmelseher, M.; Waldner, A.; Steffen, C. NMR evaluation of total statin content and HMGCoA reductase inhibition in red yeast rice (Monascus spp.) food supplements. Chin. Med. 2012, 7, 8. [CrossRef]

19. Zhu, L.; Yau, L.-F.; Lu, J.-G.; Zhu, G.-Y.; Wang, J.-R.; Han, Q.-B.; Hsiao, W.-L.; Jiang, Z.-H. Cytotoxic dehydromonacolins from red yeast rice. J. Agric. Food Chem. 2012, 60, 934-939. [CrossRef]

20. Albers-Schönberg, G.; Joshua, H.; Lopez, M.B.; Hensens, O.D.; Springer, J.P.; Chen, J.; Ostrove, S.; Hoffman, C.H.; Alberts, A.W.; Patchett, A.A. Dihydromevinolin, a potent hypocholesterolemic metabolite produced by Aspergillus terreus. J. Antibiot. 1981, 34, 507-512. [CrossRef]

21. Haruyama, H.; Kuwano, H.; Kinoshita, T.; Terahara, A.; Nishigaki, T.; Tamura, C. Structure elucidation of the bioactive metabolites of ML-236B (mevastatin) isolated from dog urine. Chem. Pharm. Bull. (Tokyo) 1986, 34, 1459-1467. [CrossRef]

22. Barber, J.; Cornford, J.L.; Howard, T.D.; Sharplese, D. The structure of citrinin in vivo. J. Chem. Soc. Perkin Trans. 1987, 1, 2743-2744. [CrossRef]

23. Lankhorst, P.P.; Poot, M.M.; De Lange, M.P.A. Quantitative determination of lovastatin and dihydrolovastatin by means of ${ }^{1} \mathrm{H}-\mathrm{NMR}$ spectroscopy. Pharmacopeial. Forum 1996, 22, 2414-2422.

24. Simpson, J. Lovastatin in chloroform-D. In NMR Case Studies. Data Analysis of Complicated Molecules, 1st ed.; Elsevier: Cambridge, MA, USA, 2017; pp. 94-104.

25. Su, N.-W.; Lin, Y.-L.; Lee, M.-H.; Ho, C.-Y. Ankaflavin from Monascus-fermented red rice exhibits selective cytotoxic effect and induces cell death on Hep G2 cells. J. Agric. Food Chem. 2005, 53, 1949-1954. [CrossRef] [PubMed]

26. Li, M.-N.; Li, C.-R.; Gao, W.; Li, P.; Yang, H. Highly sensitive strategy for identification of trace chemicals in complex matrix: Application to analysis of monacolin analogues in monascus-fermented rice product. Anal. Chim. Acta 2017, 982, 156-167. [CrossRef]

27. Endo, A. Monacolin K, a new hypocholesterolemic agent produced by a Monascus species. J. Antibiot. 1979, 32, 852-854. [CrossRef]

28. Endo, A.; Hasumi, K.; Negishi, S. Monacolins J and L, new inhibitors of cholesterol biosynthesis produced by Monascus ruber. J. Antibiot. 1985, 38, 420-422. [CrossRef]

29. Mapari, S.A.; Hansen, M.E.; Meyer, A.S.; Thrane, U. Computerized screening for novel producers of Monascus-like food pigments in Penicillium species. J. Agric. Food Chem. 2008, 56, 9981-9989. [CrossRef] [PubMed]

30. Zheng, Y.; Xin, Y.; Guo, Y. Study on the fingerprint profile of Monascus products with HPLC-FD, PAD and MS. Food Chem. 2009, 113, 705-711. [CrossRef]

31. Hsu, Y.-W.; Hsu, L.-C.; Liang, Y.-H.; Kuo, Y.-H.; Pan, T.-M. Monaphilones A-C, three new antiproliferative azaphilone derivatives from Monascus purpureus NTU 568. J. Agric. Food Chem. 2010, 58, 8211-8216. [CrossRef]

32. Chiu, H.-W.; Chen, M.-H.; Fang, W.-H.; Hung, C.-M.; Chen, Y.-L.; Wu, M.-D.; Yuan, G.-F.; Wu, M.-J.; Wang, Y.-J. Preventive effects of monascus on androgen-related diseases: Androgenetic alopecia, benign prostatic hyperplasia, and prostate cancer. J. Agric. Food Chem. 2013, 61, 4379-4386. [CrossRef]

33. Ogihara, J.; Kato, J.; Oishi, K.; Fujimoto, Y. PP-R, 7-(2-hydroxyethyl)-monascorubramine, a red pigment produced in the mycelia of Penicillium sp. AZ. J. Biosci. Bioeng. 2001, 91, 44-47. [CrossRef] 
34. Mapari, S.A.S.; Meyer, A.S.; Thrane, U. Colorimetric characterization for comparative analysis of fungal pigments and natural food colorants. J. Agric. Food Chem. 2006, 54, 7027-7035. [CrossRef] [PubMed]

35. Woo, P.C.Y.; Lam, C.-W.; Tam, E.W.T.; Lee, K.-C.; Yung, K.K.Y.; Leung, C.K.F.; Sze, K.-H.; Lau, S.K.P.; Yuen, K.-Y. The biosynthetic pathway for a thousand-year-old natural food colorant and citrinin in Penicillium marneffei. Sci. Rep. 2014, 4, 6728. [CrossRef] [PubMed]

36. Bijinu, B.; Suh, J.-W.; Park, S.-H.; Kwon, H.-J. Delineating Monascus azaphilone pigment biosynthesis: Oxidoreductive modifications determine the ring cyclization pattern in azaphilone biosynthesis. RSC Adv. 2014, 4, 59405-59408. [CrossRef]

37. Li, X.-M.; Shen, X.-H.; Duan, Z.-W.; Guo, S.-R. A new monacolin analogue from Xuezhikang capsule. Acta Pharm. Sin. 2011, 46, 564-567.

38. EFSA Panel on Dietetic Products, Nutrition and Allergies (NDA). Scientific Opinion on the substantiation of health claims related to monacolin $\mathrm{K}$ from red yeast rice and maintenance of normal blood LDL-cholesterol concentrations (ID 1648, 1700) pursuant to Article 13(1) of Regulation (EC) No 1924/2006. EFSA J. 2011, 9, 2304. [CrossRef]

39. Gordon, R.Y.; Cooperman, T.; Obermeyer, W.; Becker, D.J. Marked variability of monacolin levels in commercial red yeast rice products: Buyer beware! Arch. Intern. Med. 2010, 170, 1722-1727. [CrossRef] [PubMed]

40. Heber, D.; Yip, I.; Ashley, J.M.; Elashoff, D.A.; Elashoff, R.M.; Go, V.L. Cholesterol-lowering effects of a proprietary Chinese red-yeast-rice dietary supplement. Am. J. Clin. Nutr. 1999, 69, 231-236. [CrossRef]

41. Becker, D.J.; Gordon, R.Y.; Morris, P.B.; Yorko, J.; Gordon, Y.J.; Li, M.; Iqbal, N. Simvastatin vs therapeutic lifestyle changes and supplements: Randomized primary prevention trial. Mayo Clin. Proc. 2008, 86, 758-764. [CrossRef]

42. Becker, D.J.; Gordon, R.Y.; Halbert, S.C.; French, B.; Morris, P.B.; Rader, D.J. Red yeast rice for dyslipidemia in statin-intolerant patients: A randomized trial. Ann. Intern. Med. 2009, 150, 830-839. [CrossRef]

43. Maesschalck, J.; Gruyters, A.M.; Corthout, J. Levure de riz rouge. Que choisir et quel conseil donner? J. Pharm. Belg. 2018, 4, 6-17.

44. Endo, A. Compactin (ML-236B) and related compounds as potential cholesterol-lowering agents that inhibit HMG-CoA reductase. J. Med. Chem. 1985, 28, 401-405. [CrossRef] [PubMed]

45. Phainuphong, P.; Rukachaisirikul, V.; Saithong, S.; Phongpaichit, S.; Bowornwiriyapan, K.; Muanprasat, C.; Srimaroeng, C.; Duangjai, A.; Sakayaroj, J. Lovastatin analogues from the soil-derived fungus Aspergillus sclerotiorum PSU-RSPG178. J. Nat. Prod. 2016, 79, 1500-1507. [CrossRef] [PubMed]

46. Heinz, T.; Schuchardt, J.P.; Möller, K.; Hadji, P.; Hahn, A. Low daily dose of 3 mg monacolin K from RYR reduces the concentration of LDL-C in a randomized, placebo-controlled intervention. Nutr. Res. 2016, 36, 1162-1170. [CrossRef] [PubMed]

47. Li, Y.-G.; Liu, H.; Wang, Z.-T. A validated stability-indicating HPLC with photodiode array detector (PDA) method for the stress tests of Monascus purpureus-fermented rice, red yeast rice. J. Pharm. Biomed. Anal. 2005, 39, 82-90. [CrossRef] [PubMed]

48. Theunis, M.; Naessens, T.; Verhoeven, V.; Hermans, N.; Apers, S. Development and validation of a robust high-performance liquid chromatographic method for the analysis of monacolins in red yeast rice. Food Chem. 2017, 234, 33-37. [CrossRef]

Sample Availability: Samples of the formulations are available from the authors. 